\title{
Medicinal plants used in managing diseases of the respiratory system among the Luo community: an appraisal of Kisumu East Sub-County, Kenya
}

James Kiamba Mailu ${ }^{1,2^{*}} \mathbb{D}$, Joseph Mwanzia Nguta ${ }^{1}$, James Mucunu Mbaria ${ }^{1}$ and Mitchel Otieno Okumu ${ }^{1,3}$

\begin{abstract}
Background: Poor access to healthcare in rural communities causes many people to seek herbalists who use medicinal plants for the treatment of various disease conditions. Most knowledge of traditional herbal medicine makes use of indigenous remedies which are often undocumented and are at risk of being lost. The preservation of this knowledge may facilitate scientific inquiry into promising new therapeutic molecules.
\end{abstract}

Methods: Semi-structured questionnaires were used to collect the sociodemographic information of 30 herbalists in Kisumu East Sub County. The local names of medicinal plants used in managing illnesses of the respiratory system, their habit, active parts, indications, methods of preparation, routes of administration, scientific identity, and conservation status were also recorded. Other reported traditional uses, pharmacological activities, and toxicological data were identified via a literature search.

Results: Most herbalists were female (86.7\%), aged between 61 and 70 years (43.3\%) with no formal education (56.7\%), and had 21-30 years of practice (30\%). 44 plant species, belonging to 43 genera and 28 families were identified. Leguminosae and Rutaceae plant families were predominant, leaves were frequently used (33\%), and trees were the most common habit (44.4\%). Most plants were collected in the wild (79.2\%), preparation was mainly by decoction (68.8\%), and the administration was mainly orally. The main indication was cough and $79.5 \%$ of all documented plant species had previously been reported to have a pharmacological activity relevant to the mitigation of respiratory illnesses. Toxicological data was available for $84.1 \%$ of the plant species identified.

Conclusions: The predominant use of roots, root barks, and root tubers by herbalists in Kisumu East Sub County threatens to negatively impact the ecological survival of some plant species. The preservation of herbalists' knowledge of medicinal plants in the study area is a pressing concern considering their advanced age and little formal education. There is a need to conserve some of the medicinal plants documented in this study. The medicinal claims made by herbalists also warrant scientific scrutiny.

Keywords: Ethnopharmacology, Medicinal plants, Kisumu East, Luo, Ethnomedicinal, Ethnobotanical, Respiratory diseases, Cough

\footnotetext{
*Correspondence: jkmailu@gmail.com

${ }^{1}$ Department of Public Health, Pharmacology, and Toxicology, Faculty of Veterinary Medicine, University of Nairobi, P.O Box 29053-00625, Nairobi, Kenya

Full list of author information is available at the end of the article
}

\section{Background}

The global burden of respiratory diseases makes for daunting reading. Lower respiratory tract infections (LRTI) and chronic obstructive pulmonary disease (COPD) reportedly claimed 6 million human lives in

c) The Author(s) 2020. This article is licensed under a Creative Commons Attribution 4.0 International License, which permits use, sharing, adaptation, distribution and reproduction in any medium or format, as long as you give appropriate credit to the original author(s) and the source, provide a link to the Creative Commons licence, and indicate if changes were made. The images or other third party material in this article are included in the article's Creative Commons licence, unless indicated otherwise in a credit line to the material. If material is not included in the article's Creative Commons licence and your intended use is not permitted by statutory regulation or exceeds the permitted use, you will need to obtain permission directly from the copyright holder. To view a copy of this licence, visit http://creativeco mmons.org/licenses/by/4.0/. The Creative Commons Public Domain Dedication waiver (http://creativecommons.org/publicdomain/ zero/1.0/) applies to the data made available in this article, unless otherwise stated in a credit line to the data. 
2016 [1]. The prevalence of COPD in Sub Saharan Africa has been reported to be between 4 and 25\% and > 100,000 deaths have been linked to non-communicable diseases including those of the respiratory system [2,3]. Diseases of the respiratory system hurt individual productivity and are responsible for more than $10 \%$ of all disabilityadjusted life years [4].

According to a 2013 Kenya National Bureau of Statistics (KNBS) economic survey, pneumonia, and tuberculosis were responsible for $13.7 \%$ of all total deaths in the Nyanza region [5]. It is important to note that illnesses of the upper respiratory tract are the second leading cause of death in Kisumu County [6]. Poor access to healthcare and scarcity of health resources in rural areas such as many parts of Kisumu East Sub County causes many inhabitants of such areas to rely on indigenous plant resources to manage common diseases including those that affect the respiratory system. Plant-based indigenous remedies may be key in the future management of respiratory system diseases [7]. However, the potential of this resource is largely untapped due to inadequate documentation by the herbalists who prepare the remedies.

The rapid development of infrastructure in Sub Saharan Africa including Kenya threatens to destroy cultural lands where medicinal plants are cultivated. This is problematic given that the knowledge of these plant resources is mostly an extension of people's culture $[8,9]$. Herbalists are usually the custodians of medicinal plants in these communities. By documenting the knowledge held by herbalists, vital information on the medicinal plants may be preserved. The current study aimed to collect ethnobotanical data on medicinal plants used by herbalists in the management of respiratory diseases in Kisumu East Sub County.

\section{Materials and methods}

\section{Ethical approval and consent to participate in the study}

Ethical approval for the study was obtained from the Biosafety, Animal Use and Ethics committee of the University of Nairobi (Ref: FVM BAUEC/2019/210). Approval was additionally sought from regional administrators (the area chief and assistant chief) who were duly notified of the study's objectives. The scope, possible benefits, and risks of the study were explained to willing participants (herbalists) and consent forms were made available to them for signing.

\section{Study area}

The study was conducted in Kisumu East Sub County in Western Kenya (Fig. 1). The study area is approximately $365 \mathrm{~km}$ from Nairobi (the administrative capital of Kenya) and covers an area of approximately $135 \mathrm{~km}^{2}$. It lies within latitudes $0^{\circ} 20^{\prime}$ South and $0^{\circ} 50^{\prime}$ South and longitudes $33^{\circ} 20^{\prime} \mathrm{E}$ and $35^{\circ} 20^{\prime} \mathrm{E}$ and comprises of several administrative wards including Kolwa Central, Kolwa East, Manyatta B, Nyalenda A, and Kajulu East and West [10]. Moreover, the population in this area is about 220,977 according to the 2019 Kenya Population and Housing Census [5]. It receives an annual relief rainfall of between 1200 and $1300 \mathrm{~mm}$ and annual temperatures range between 20 and $35{ }^{\circ} \mathrm{C}$. The major economic activities of residents include fish farming, and agriculture (sugar, livestock, and poultry farming) [10].

\section{Data collection}

The study was conducted between March and September 2019. Ethnobotanical data were obtained by using semistructured questionnaires. The target respondents were local herbalists with good ethnobotanical knowledge of the plants used in managing respiratory diseases and related symptoms. Thirty local herbalists were selected for interviews which were conducted both in Kiswahili and Luo dialect with the aid of a botanist familiar with the languages. Each of the respondents was interviewed individually to ensure confidentiality. The interviews sought to answer the following questions;

- Which plant parts are most commonly used in preparing the indigenous remedies indicated for respiratory illnesses?

- Which methods are adopted in preparing the indigenous remedies?

- Which respiratory illnesses are most commonly treated with medicinal plants in the study area?

- Which plant species are used in the preparation of the remedies?

- How are the indigenous remedies administered? See Additional file 1.

\section{Collection and identification of plant specimens}

Several trips were made to the homesteads of the herbalists where voucher specimens were collected and pressed and later identified by a botanist before being deposited at the University of Nairobi Herbarium. Information on the vernacular name, plant part used, plant habit (i.e. the general appearance, growth form, or architecture), plant status, method of preparation, and route of administration were collected.

\section{Literature search strategy}

A literature search was conducted on MEDLINE, PubMed, PubMed Central (PMC), Google Scholar, the Directory of Open Access Journals (DOAJ), The Journal Author Name Estimator (JANE), University repositories, and from grey literature to identify relevant articles/ 
Kisumu East Subcounty.

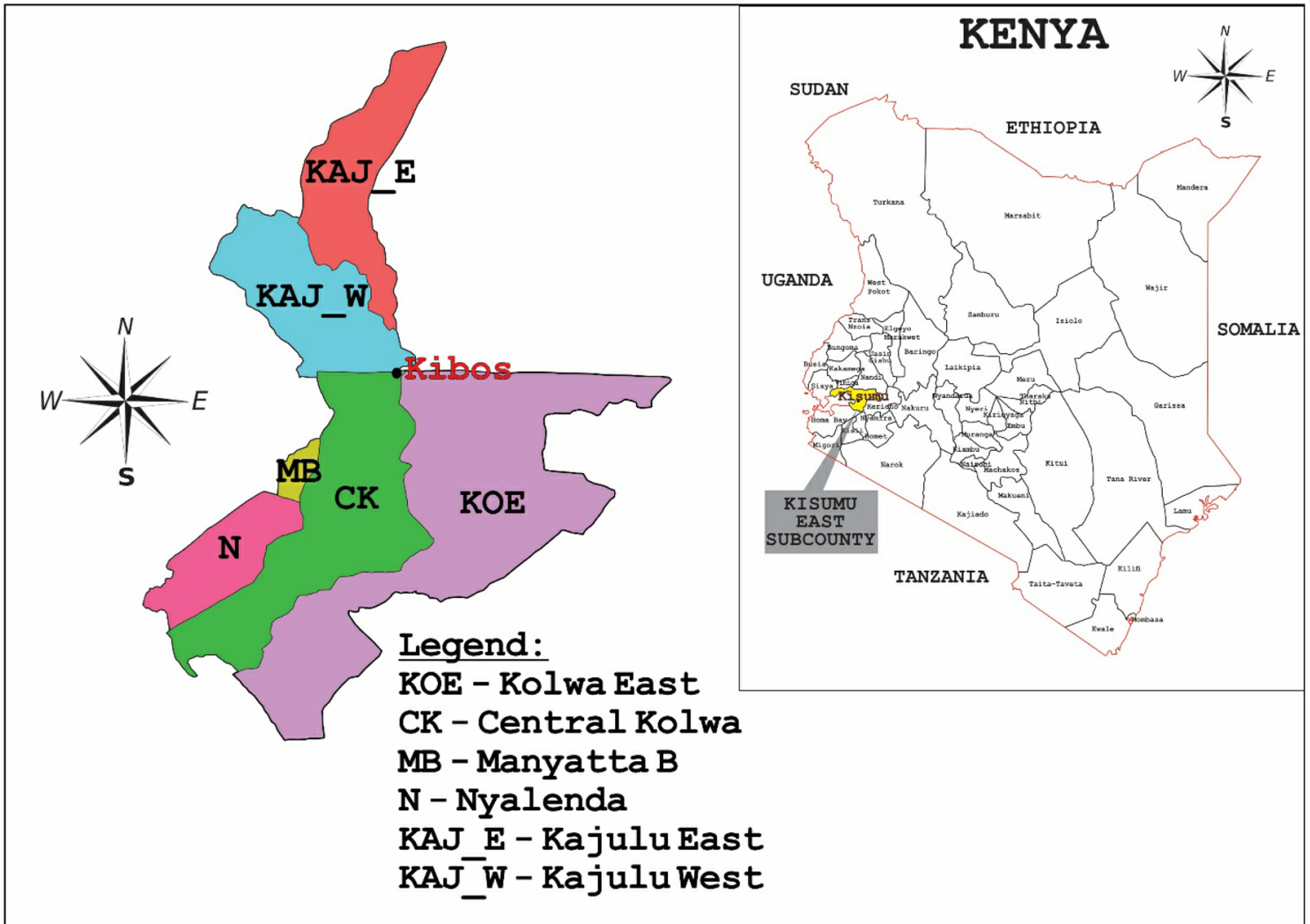

Fig. 1 Map of Kenya showing Kisumu County and Kisumu East Sub County

theses/ reference material containing information on previously reported traditional uses, pharmacological/ chemical activities, and toxicological data on the medicinal plants indicated for the management of respiratory illnesses in Kisumu East Sub County. Studies were excluded if they were not in English.

\section{Data analysis}

Frequencies and percentages were used to analyze the sociodemographic data of the herbalists. The relative frequency of citation (RFC) was used to evaluate the ethnobotanical data.

\section{Relative frequency of citation (RFC)}

This was done to determine the number of herbalists who considered particular plant species were worth mentioning in the management of diseases of the respiratory system. The value was calculated using the formula described by Tardio and Santayana [11];

$$
\mathrm{RFCs}=\frac{F C s}{N}=\sum_{i=i 1}^{i N} U R i / N
$$

where Fc is the number of herbalists who cited a particular species and $\mathrm{N}$ is the total number of herbalists (Table 1).

\section{Results}

\section{Socio-demographic characteristics of the herbalists who} were interviewed

$86.7 \%$ of all herbalists were female, and aged between 61 and 70 years of age $(43.3 \%)$ (Table 1$)$. The average age of the female herbalist was 61.6 years while the average age of their male counterparts was 51.5 years of age. Seventeen of the herbalists $(56.7 \%)$ had no formal education while only 1 had secondary education (Table 1 ). It was observed that both male and female herbalists had extensive years of practice. The mean years of practice for male and female herbalists in the study area were 27 years and 25 years for male and female herbalists respectively.

\section{Diversity of medicinal plants identified and their use}

Table 2 is a summary of the family, scientific name, local name, voucher number, habit, status, and the part used, indication, method of preparation, route of administration and relative frequency of citation of 


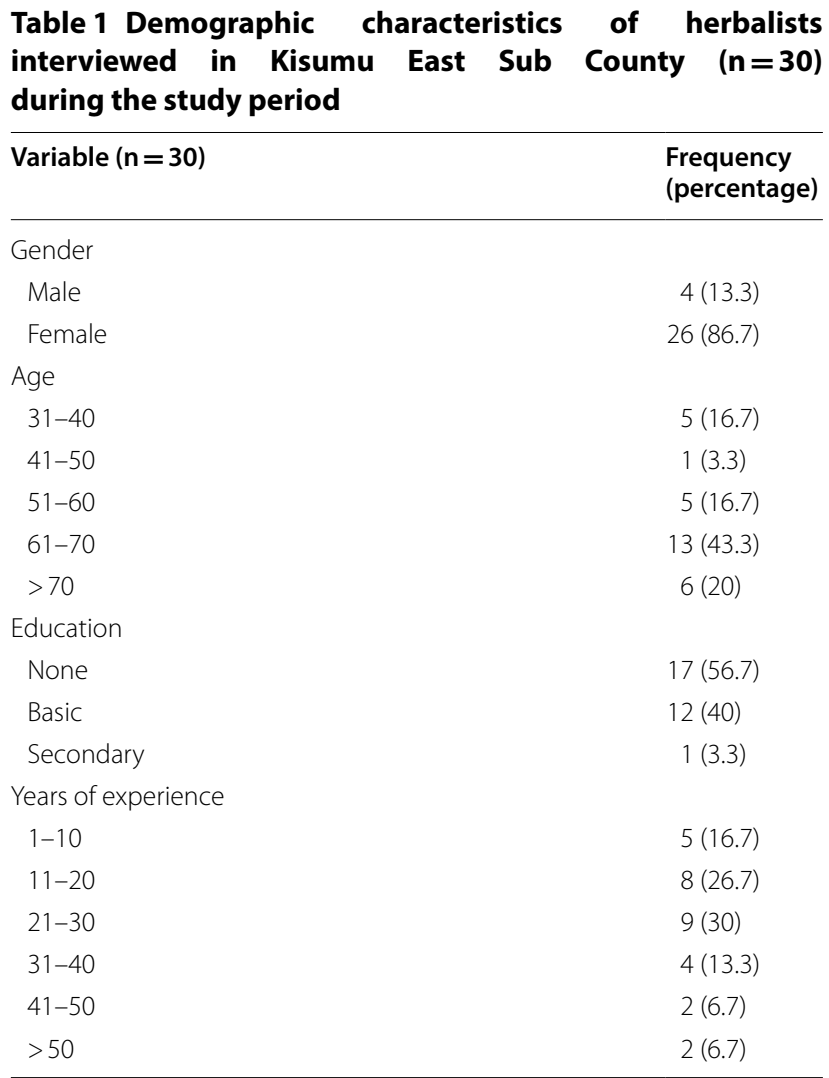

medicinal plants used in managing respiratory diseases by herbalists in Kisumu East Sub County. Forty-four plant species belonging to 43 genera distributed among 28 families were reportedly used in herbal preparations for the management of respiratory infections (Table 2). Leguminosae and Rutaceae families predominated with 5 species each, followed by Asteraceae and Lamiaceae families with 3 species each (Fig. 2). Euphorbiaceae, Meliaceae, Myrtaceae, Rubiaceae, and Vitaceae family had 2 species each (Fig. 2). The other families had 1 species only. The identified 44 species comprised of trees $(44.4 \%)$, shrubs $(37.8 \%)$, herbs $(8.9 \%)$, climbers (6.7\%), and corms (2.2\%) (Table 2). A majority of the plants were sourced from the wild $(79.2 \%)$ while some were grown in the homestead (20.8\%). The most cited plants were Euclea divinorum, Tylosema fassoglensis, Carissa edulis, Harrisonia abyssinica, Zanthoxylum gilletii, and Warburgia salutaris with RFC values of 0.73 , $0.67,0.67,0.6,0.5,0.47$ and 0.47 respectively (Table 2 ).

The different plant parts used by herbalists to manage respiratory illnesses in Kisumu East Sub County are summarized in Fig. 3. Leaves were the most frequently used parts (33\%), followed by roots (28\%) and stem bark (24\%). Root bark, fruits, corms, bulbs, and root tubers accounted for $15 \%$. Roots, root bark, root tuber, and stem bark accounted for $60 \%$ of plant parts used in the management of diseases of the respiratory system (Fig. 3).

Dosage, mode of preparation, and route of administration Various methods were used to prepare herbal medicine used for managing diseases of the respiratory system in the study area (Table 2). The most common method was decoction (68.8\%), concoction (20.8\%), and chewing (4.2\%) (Table 2). Other methods of preparation included cold maceration, powdering, and crushing before instillation in the nostrils which accounted for $2.1 \%$ respectively (Table 2). The main route of administration of the indigenous remedies prepared by the traditional medicine practitioners was oral (Table 2).

\section{Pharmacological and toxicological reports on the medicinal plants documented in this study}

Of the 44 plant species documented in this study, 95.5\% had studies that had reported their pharmacological/ chemical activity (Table 3). Moreover, 79.5\% (35/44) of the documented medicinal plants had previously been reported to be effective against microorganisms that are associated with respiratory illnesses and $84.1 \%$ of the plant species had toxicological data (Table 3).

\section{Discussion}

\section{Socio-demographic information of herbalists in the study} area

Many of the herbalists interviewed in this study were older members of the society. It has previously been reported that traditional herbal practice is usually a preserve of the older members of the society [240, 241]. It is also important to note that it is often harder for the younger generation of herbalists to be accepted by their communities as they are considered to be inexperienced in key tenets of traditional herbal medicine [240, 241]. The observation that many of the interviewed herbalists had not received any formal education seems to agree with what has been observed by other authors [241].

\section{Diversity of medicinal plants identified in the study area and their use}

The Leguminosae plant family was the most dominant family indicated for respiratory illnesses in the study area. According to Christenhusz and colleagues, Leguminosae has a large global distribution and is the 3rd largest plant family in the world (after Orchidae and Asteraceae) [242]. The worldwide distribution of this plant family may have some influence on the decision of herbalists to use the plants from this family [243].

The predominance of trees as a source of herbal therapies may have something to do with their abundance, easy availability throughout the year, and resistance to 


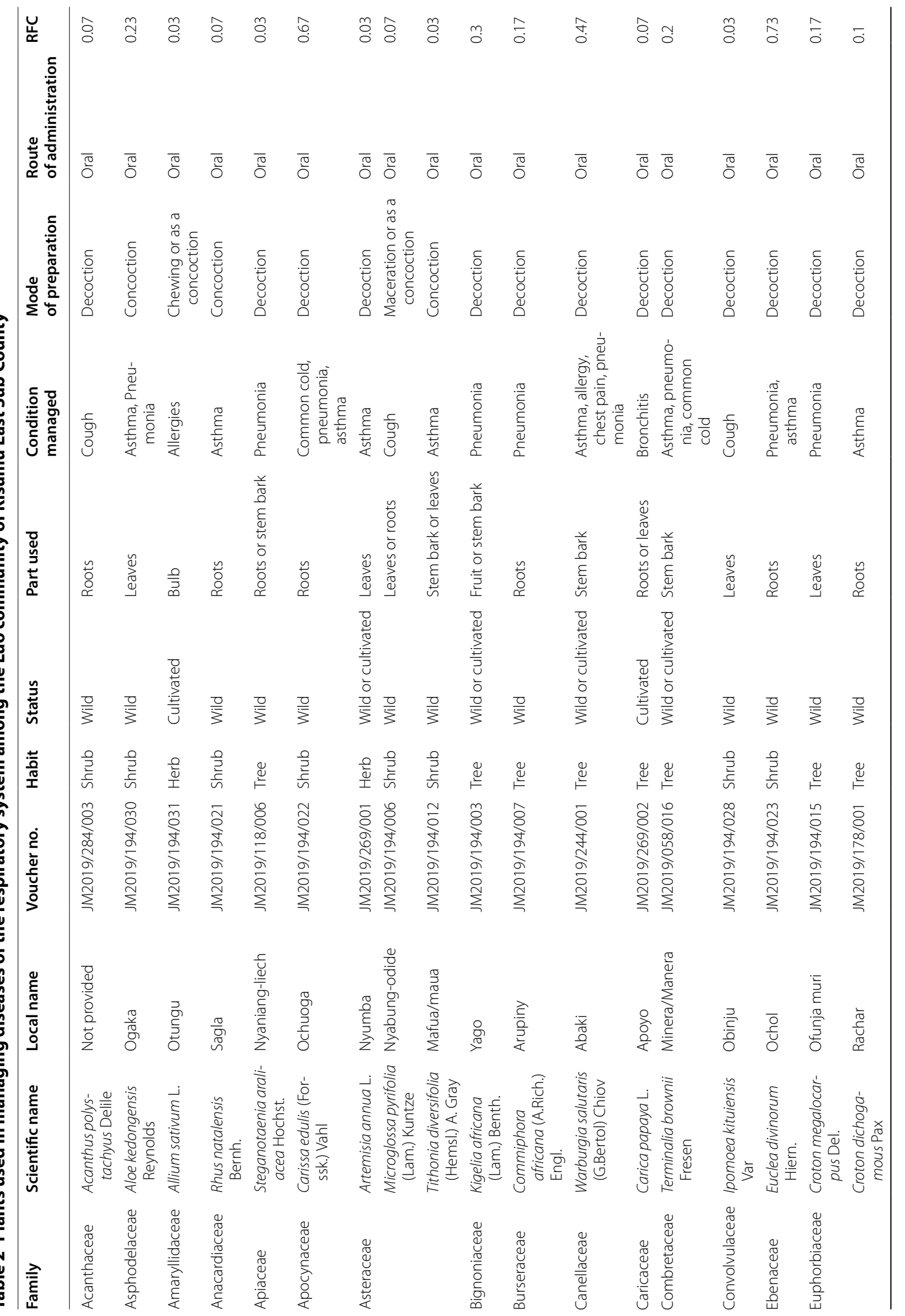




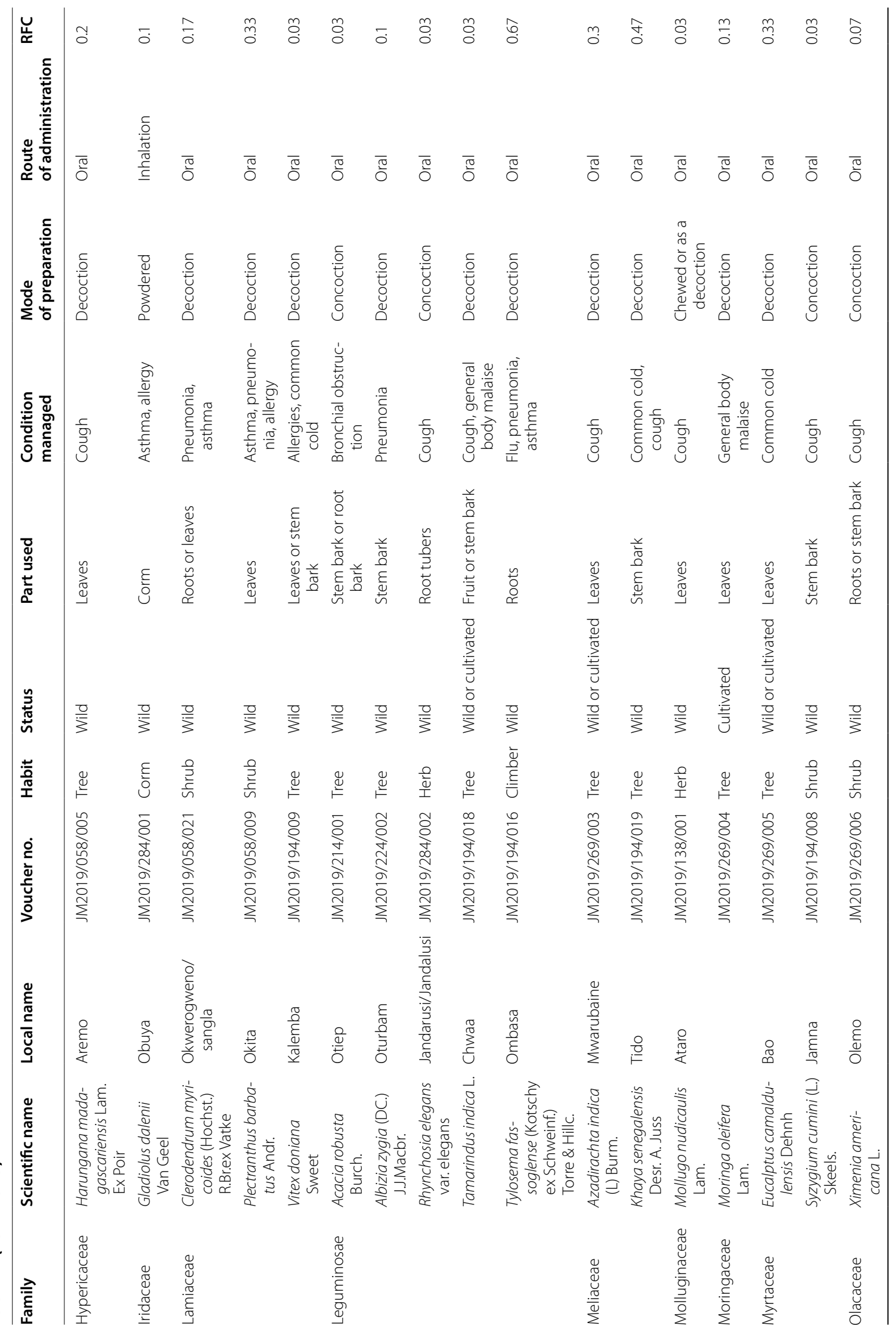




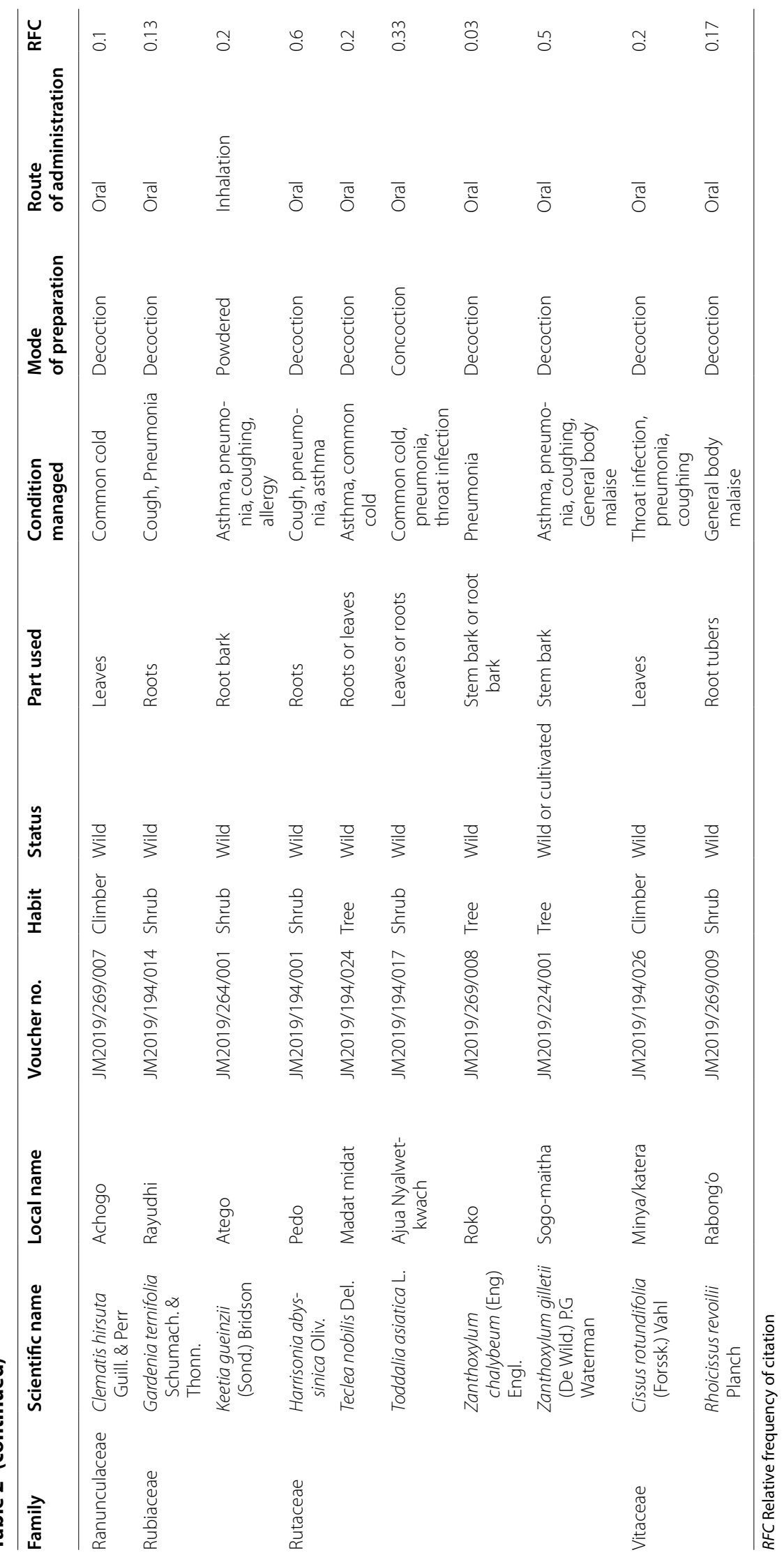




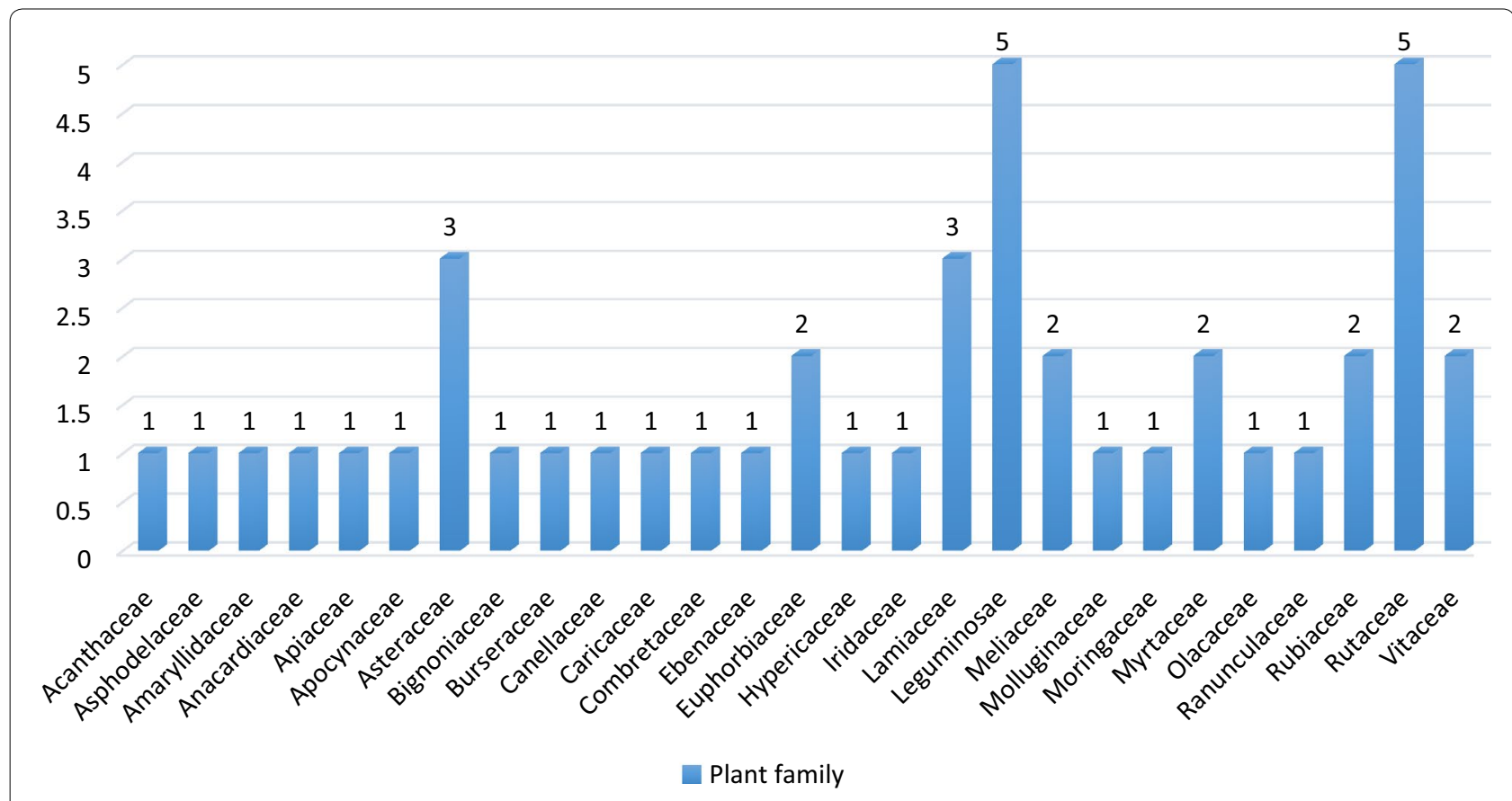

Fig. 2 Plant families used by herbalists in Kisumu East Sub County to manage diseases of the respiratory system

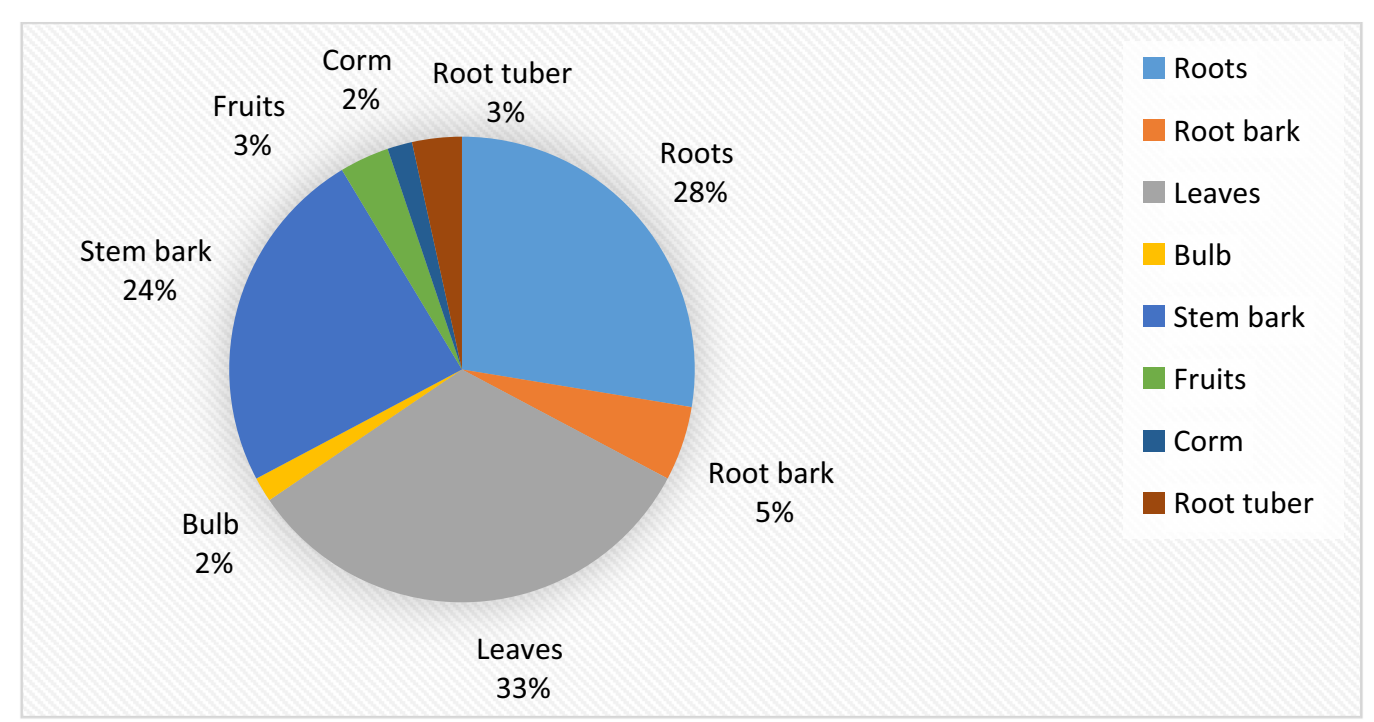

Fig. 3 Plant parts used by herbalists in Kisumu East Sub County to manage diseases of the respiratory system

drought and seasonal variations [243-245]. Leaves are considered by herbalists to be important photosynthetic organs $[241,243]$. Thus, it is not surprising that they were the most frequently used plant parts in the study area.

It was disturbing to note that many of the herbalists in the area were uprooting the plants that they used for making some of the indigenous remedies. Furthermore, in the course of the interview, some of the herbalists had reported that Warburgia salutaris and Zanthoxylum gilletii were no longer available in some parts of Kisumu East Sub County owing to poor conservation practices. According to Maroyi, it is not advisable to over use the roots and stem barks of plants for medicinal value as this may sabotage plant conservation efforts [246]. Notwithstanding, some herbalists reported that they only collected plant parts in quantities that were enough for 


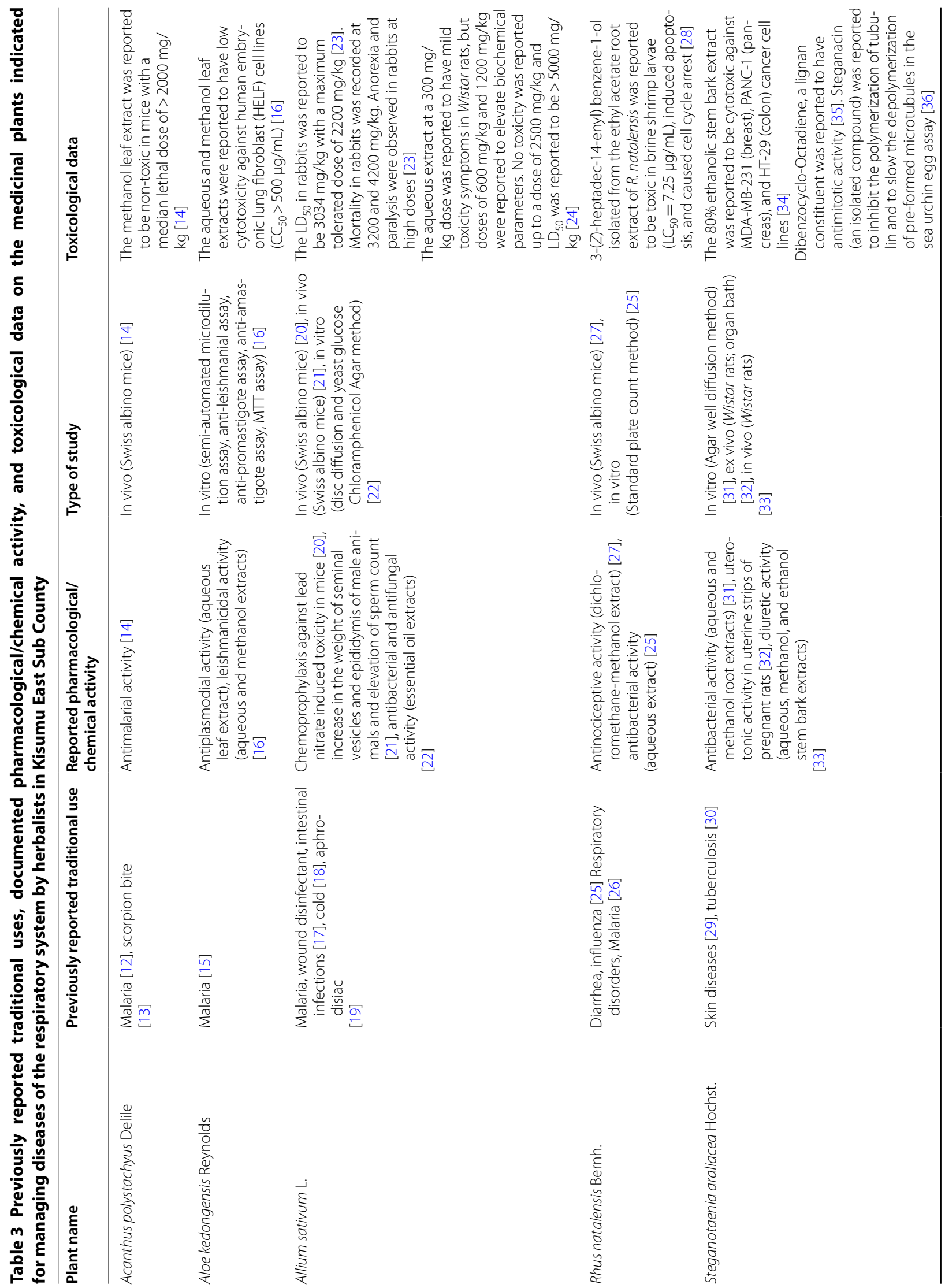




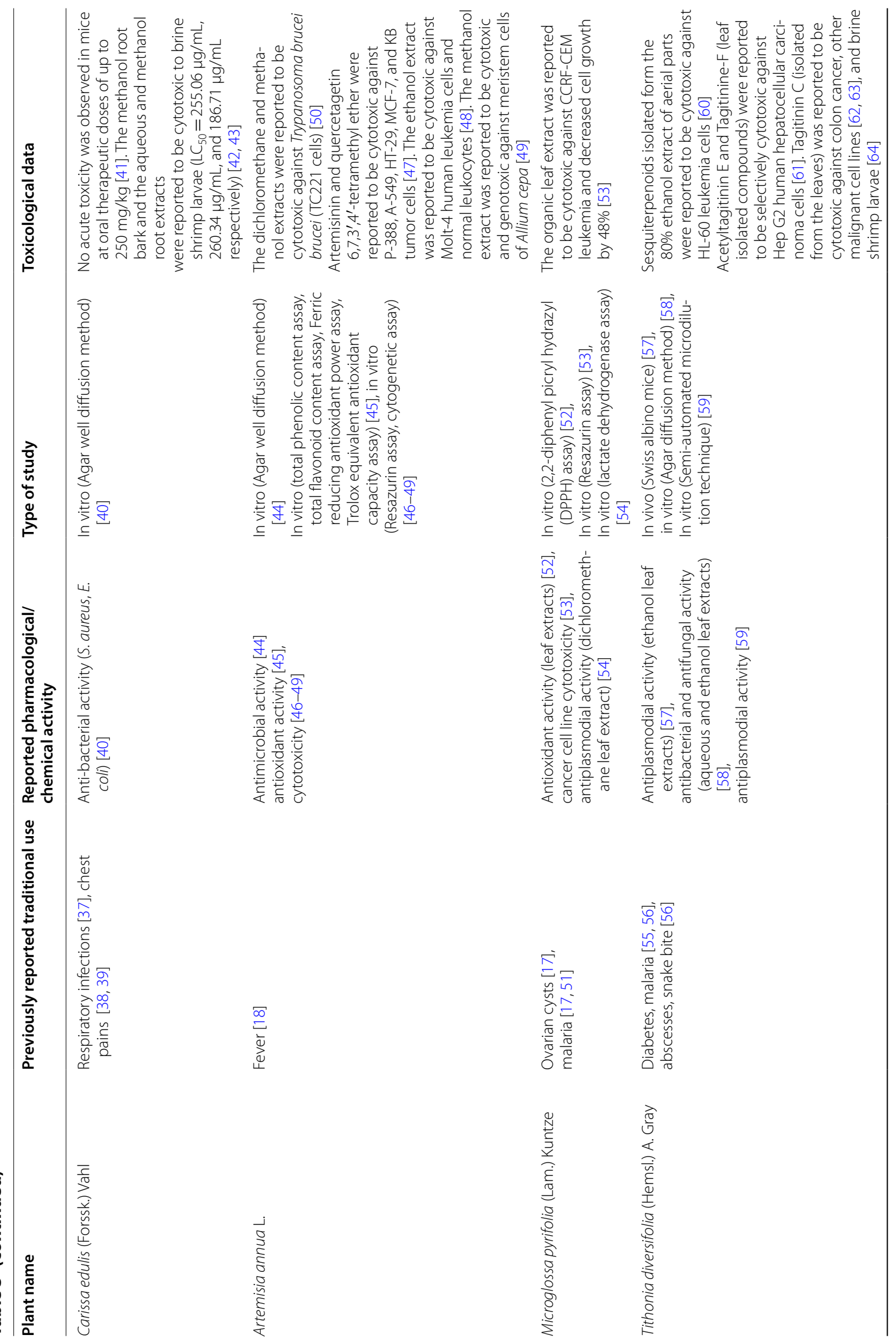




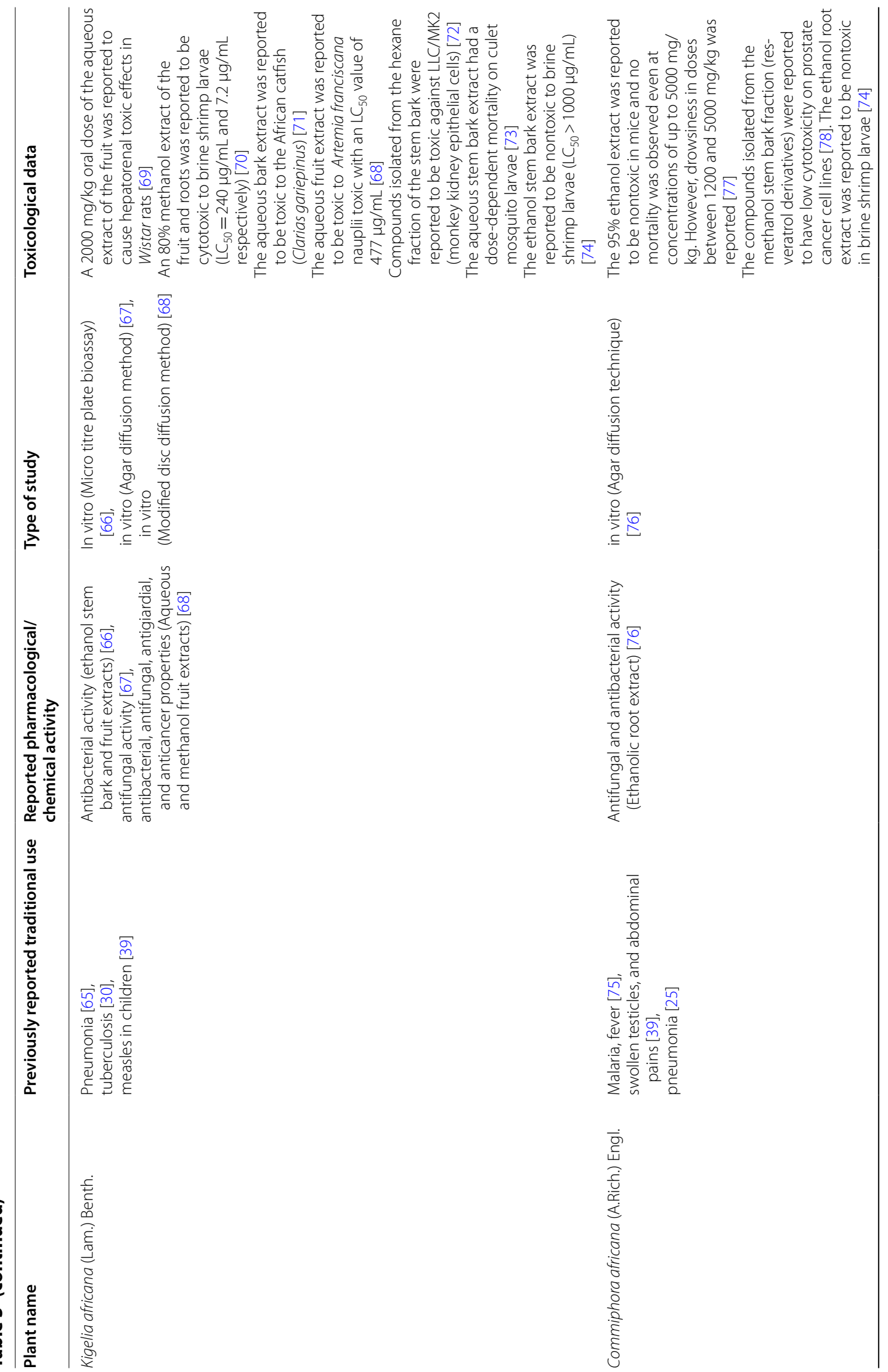




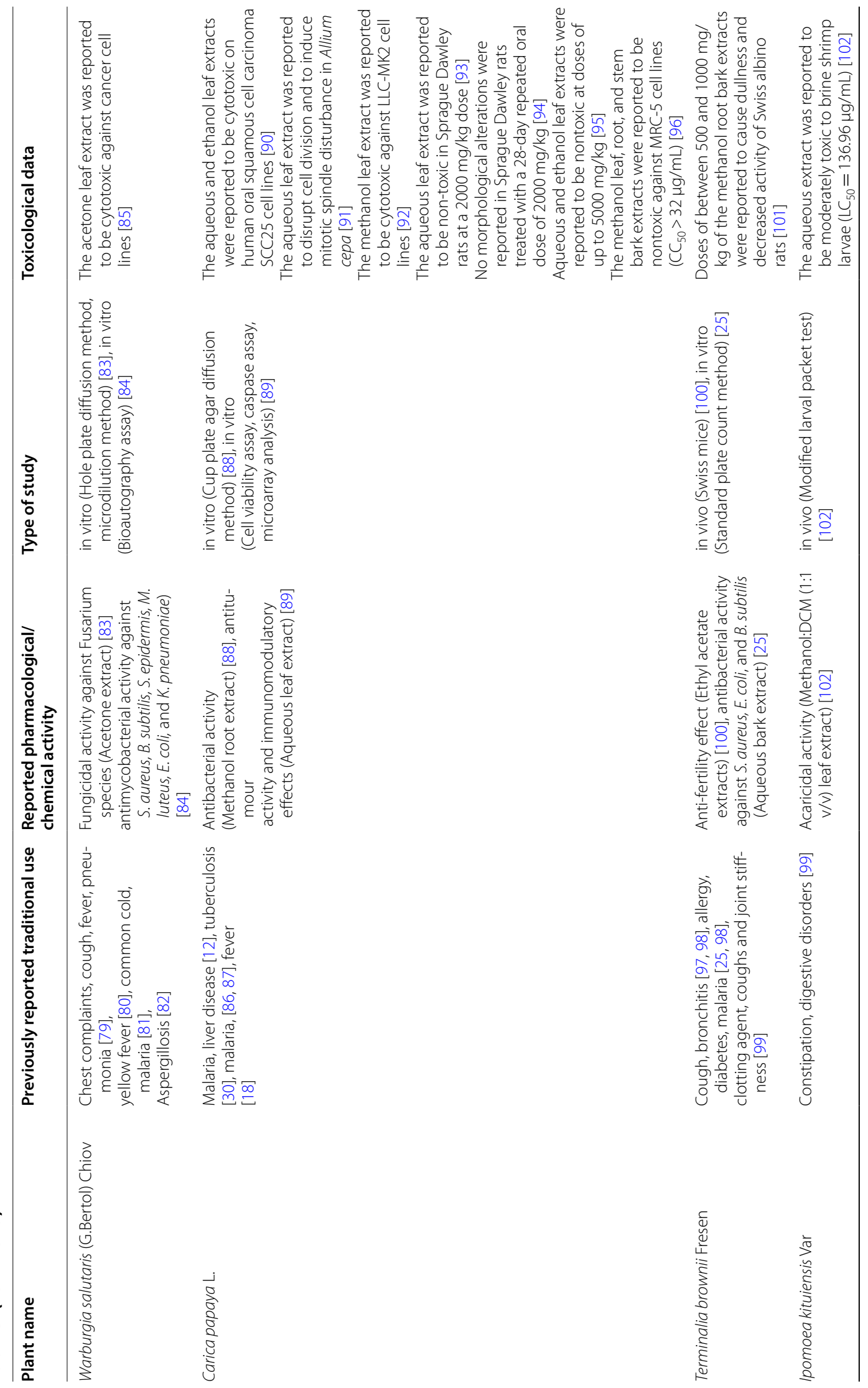




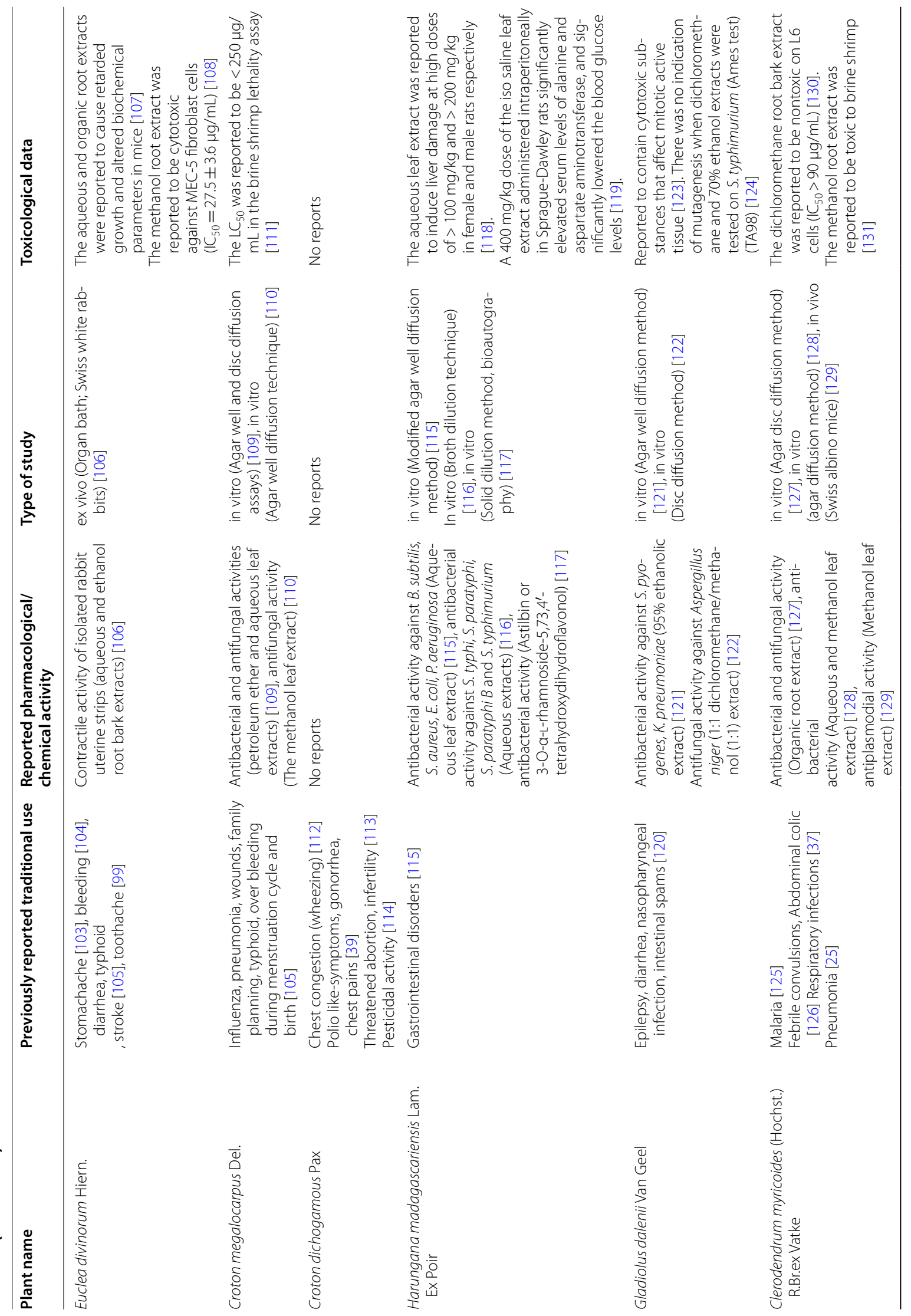




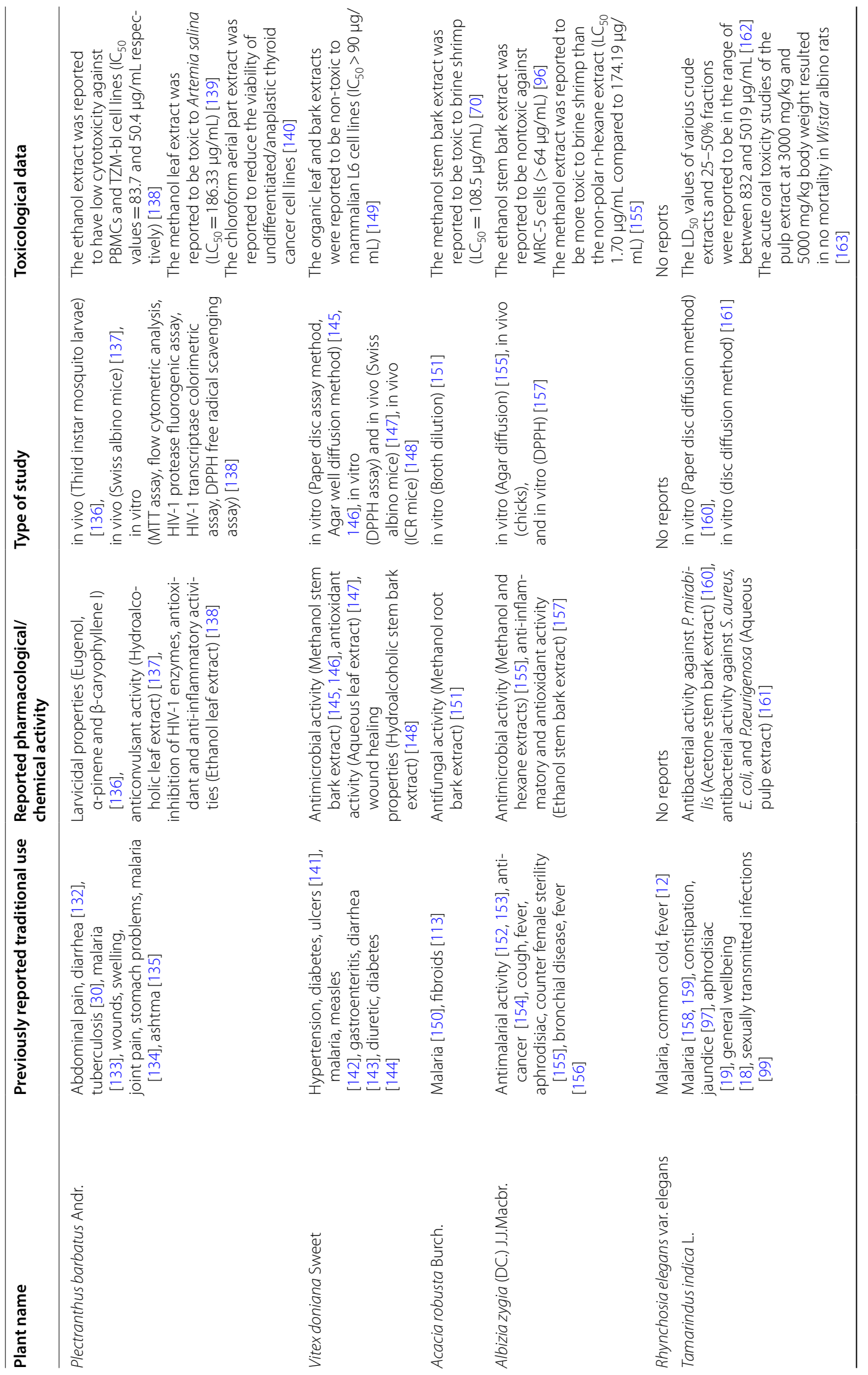


Mail et al. Chin Med $\quad$ (2020) 15:95

Page 15 of 27

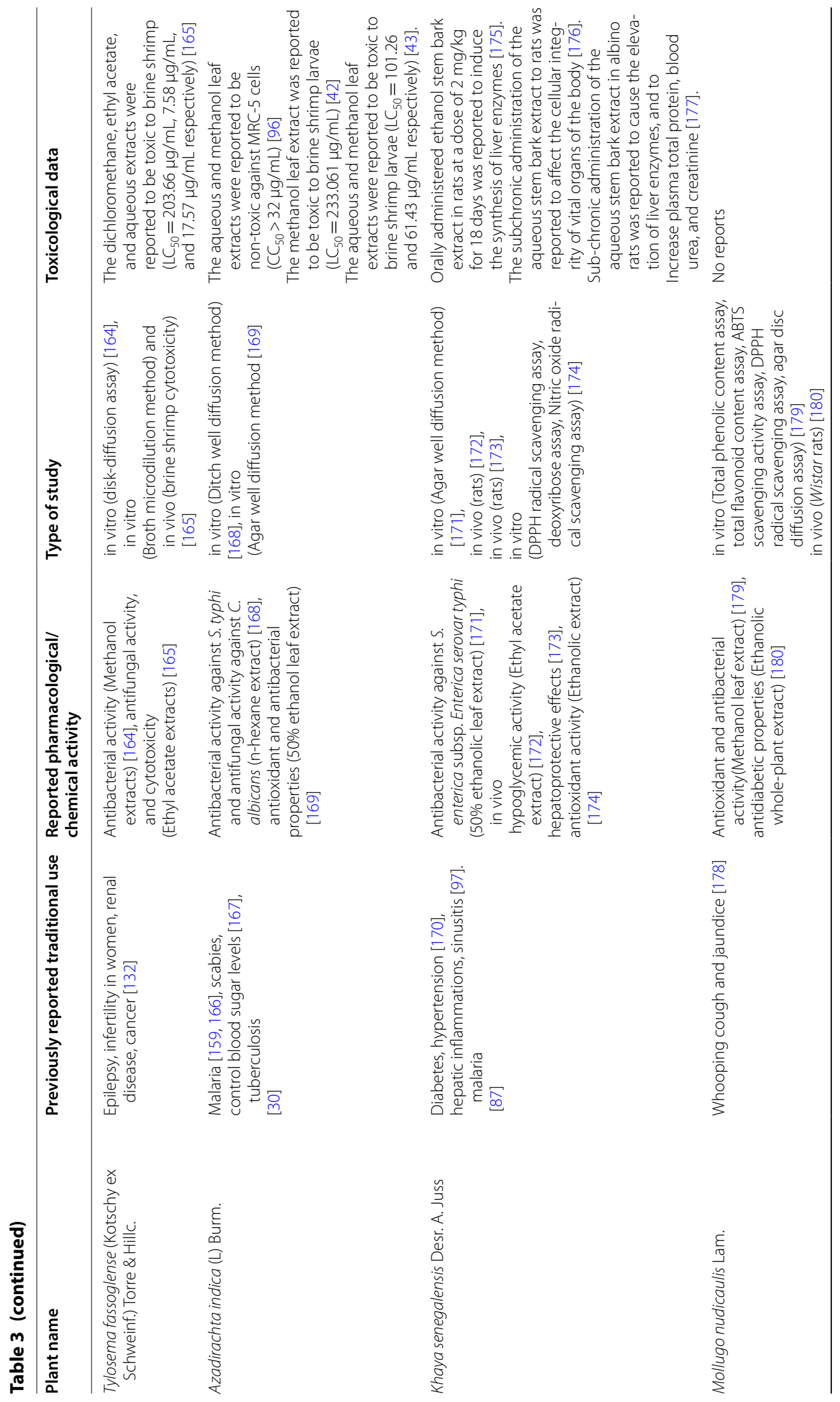




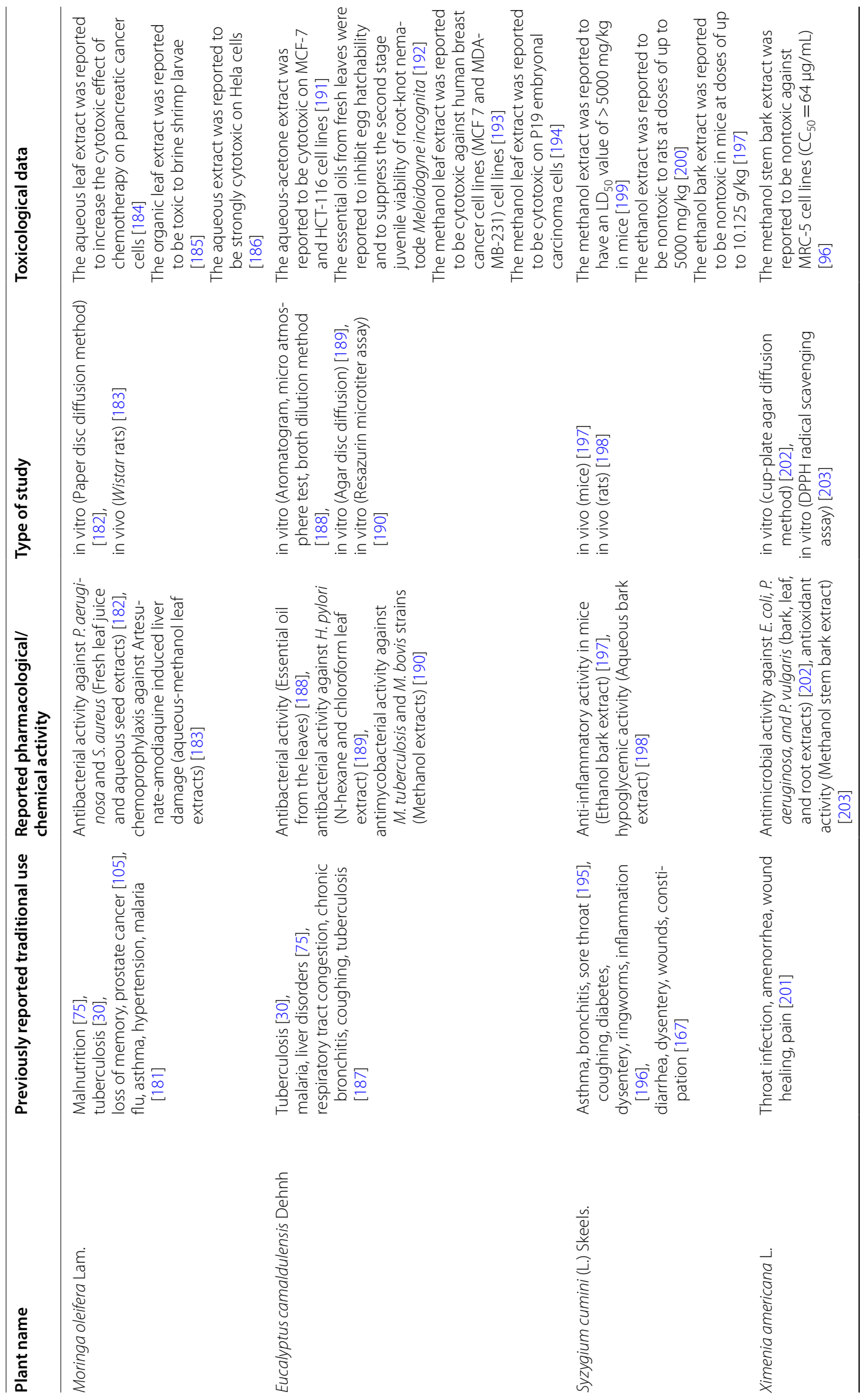




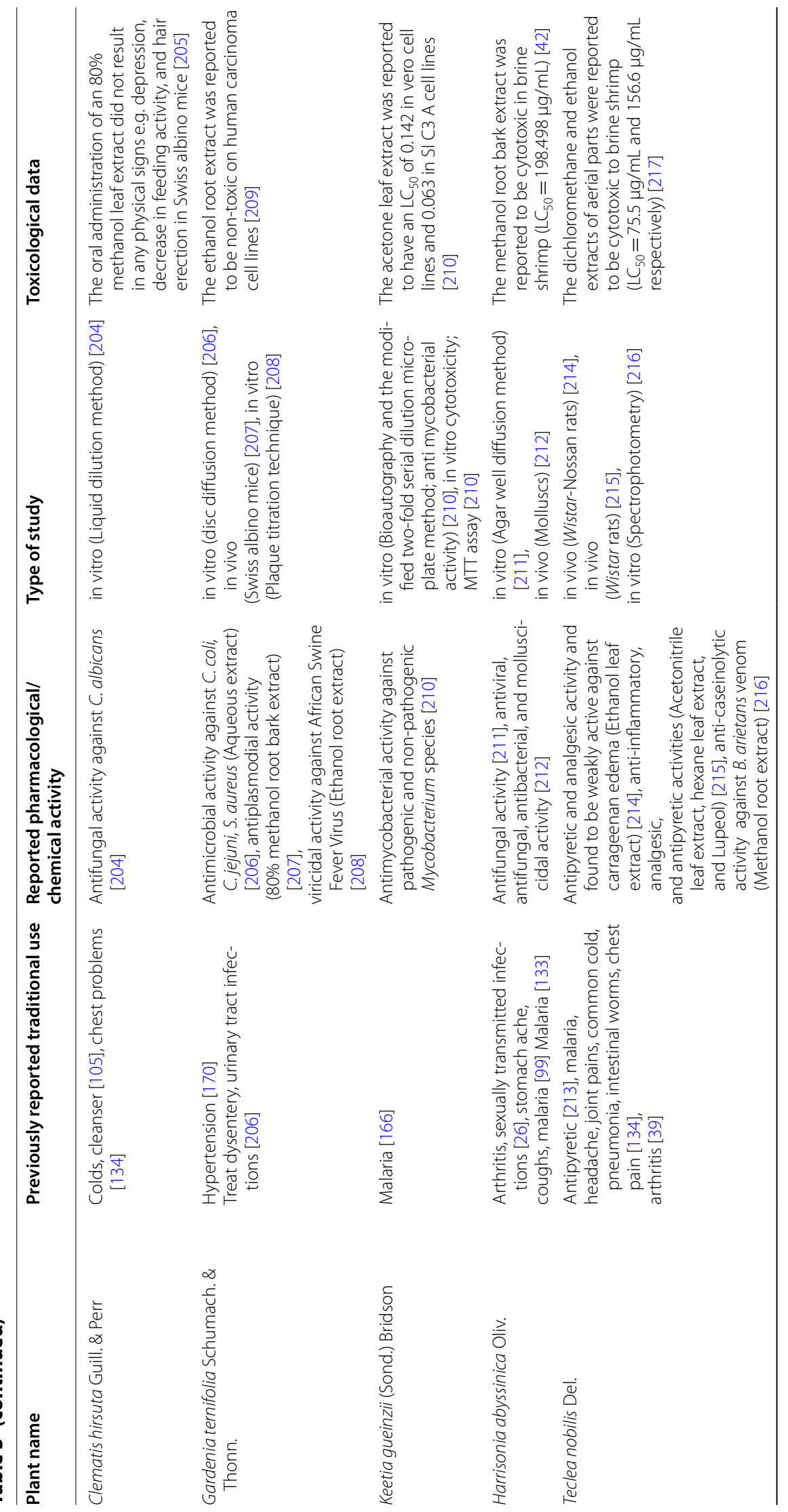




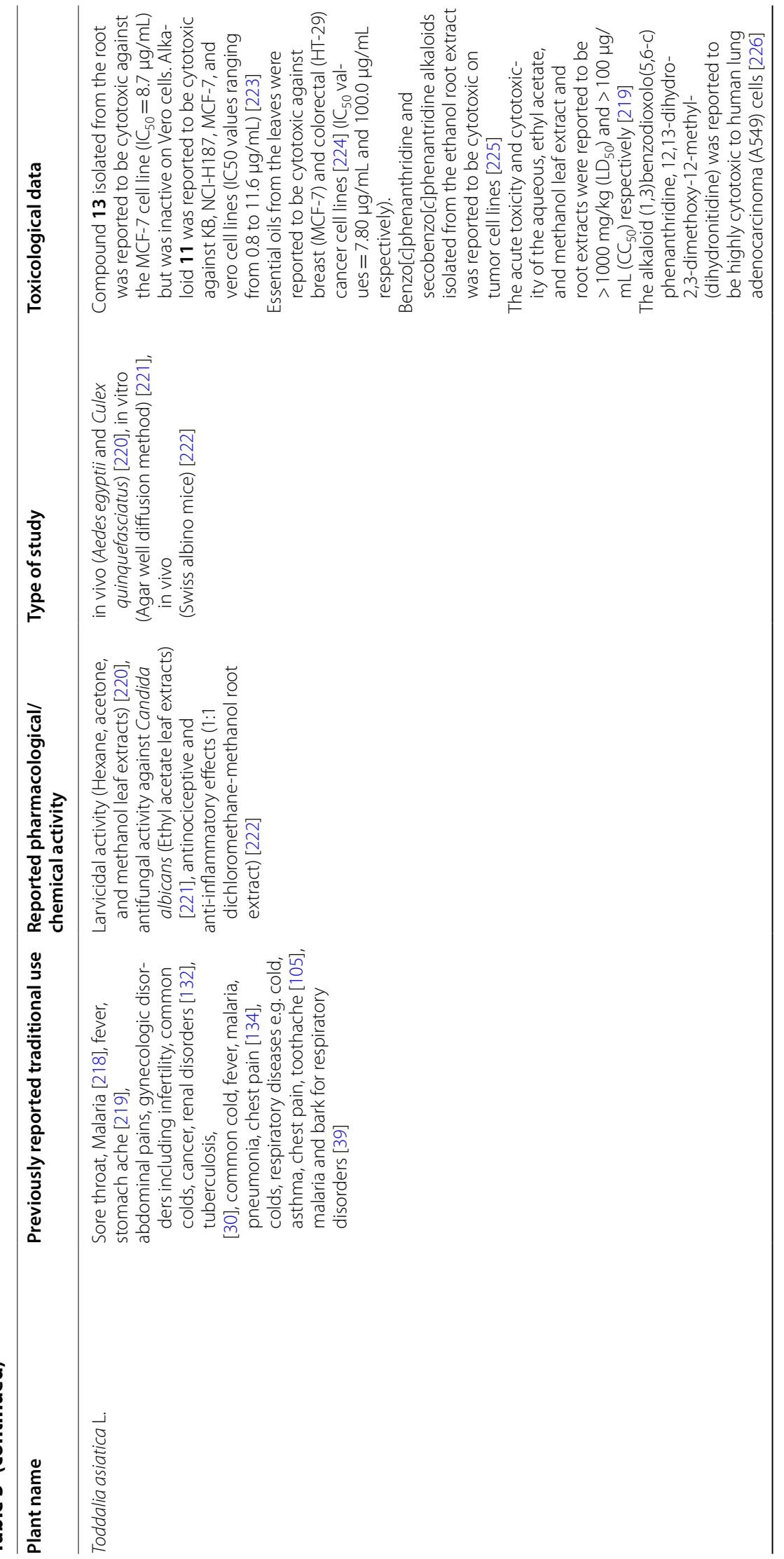




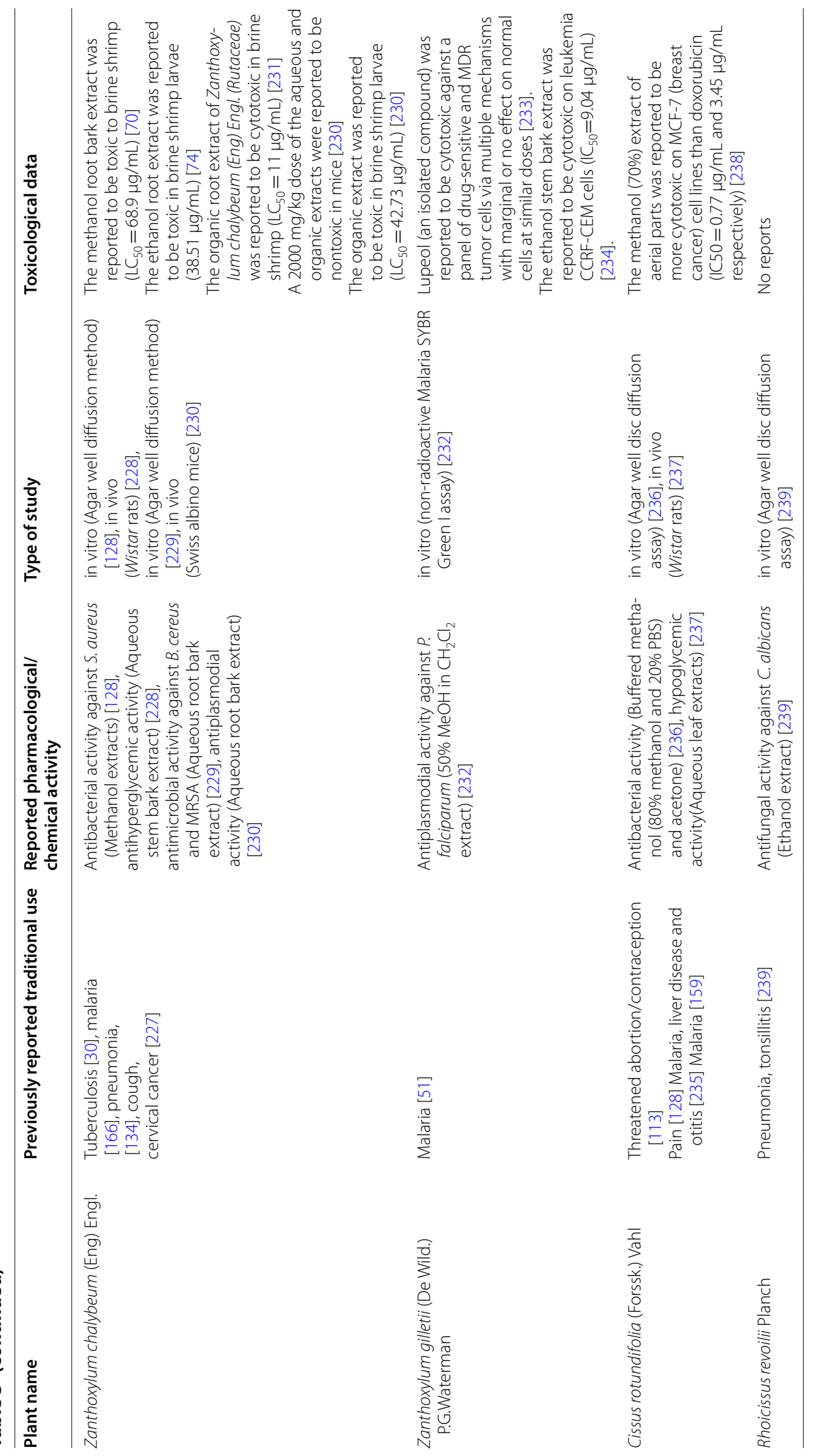


their work and which would not hamper conservation efforts. It is also worth mentioning that a local name for Acanthus polystachyus was not available. Instead, there was a consensus among the interviewed herbalists that 'Nyanandi' was the closest semblance to a name that this plant could be given on account of the assertion that it may have originally have been brought in from Nandi County which happens to be an immediate neighbor of Kisumu County.

\section{Dosage, mode of preparation, and route of administration}

Teaspoons and tablespoons were used for measuring the dosages of powdered plant materials such as barks, stems, or roots while glasses or cups were used for measuring doses of concoctions or decoctions. While the use of $300 / 500 \mathrm{~mL}$ cups was commonly recommended by the herbalists as a means of measuring the dosages of concoctions/decoctions to be used, there was ambiguity in how this was applied. This trend was also observed in a previous report where medicinal plants used for maternal healthcare in Katsina state, Nigeria were surveyed [18].

Decoctions and concoctions were the most common method of preparing indigenous remedies and was done by the herbalist or by the patient who was given instructions on how to make the preparation. The process often involved harvesting the plants, drying them in the sun or in the house for a period of several days, and crushing them into powder with the aid of a homemade mortar and pestle.

The preparations would then be stored in plastic soda bottles that varied between $500 \mathrm{~mL}$ and $2 \mathrm{~L}$ and sold to the patients directly or in the market. Powdered plant parts could be included in tea and administered orally.

The route of administration was majorly orally. In the case of Eucalyptus camaldulensis, decoctions were prepared by boiling the leaves in an earthen pot and the patient was advised to cover themselves with a blanket such that the emanating steam completely engulfed them. This was done over a period of time and the patient would later be advised to take 2 teaspoons of the decoction in the event that they had a common cold. Patients were asked to revert back to the herbalist for further directions in case they did not feel better. It is worth noting that many of the interviewed herbalists were of the opinion that their remedies rarely failed. In the minds of the herbalists, the failure of the remedies to work was largely due to the incapacity of the patients to follow the instructions issued by the herbalists.

The interviewed herbalists were of the opinion that their remedies had minimal side effects. However, it is not clear whether these herbalists had the capacity to identify any adverse events or whether they had any mechanisms to report such cases whenever they occurred.
Pharmacological reports and toxicology of the medicinal plants documented in this study

To the best of our knowledge, this is the first study to document the medicinal plants used in the management of respiratory illnesses by herbalists in Kisumu East Sub County. It is interesting to note that up to $84.1 \%$ of the medicinal plants documented in this study have previously been reported to be effective against Staphylococcus aureus, Escherichia coli, Pseudomonas aeruginosa, Aspergillus spp, and Candida albicans. These microorganisms have been associated with pneumonia and tonsillopharyngitis [247].

The most cited plants in this study were Warburgia salutaris, Zanthoxylum gilletii, Carissa edulis, Tylosema fassoglensis, and Harrisonia abyssinica. Carissa edulis and Clerodendrum myricoides have been reported to be useful in the management of asthma, cough, and cold $[37,105]$. The similarity of our observations to those made by previous authors seems to suggest that there may in fact be a consensus among herbalists from different communities with regard to the usefulness of some of the medicinal plants in their environment.

Toxicological data was not available for 4 species of plants including Croton dichogamous, Rhynchosia elegans, Mollugo nudicaulis, and Rhoicissus revoilii. Moreover, there was no pharmacological data on Croton dichogamus, and Rhynchosia elegans. This may be a potential gap that may need filling in the future.

\section{Conclusions}

The predominant use of roots, root barks, and root tubers in preparing decoctions by herbalists in the study area threatens the ecological survival of some of the plant species used. The preservation of ethno medicinal knowledge in the study area is a pressing concern considering the advanced age and little formal education of the herbalists interviewed. Plans to conserve some of the medicinal plants documented in this study should be initiated. There is a need to scientifically scrutinize the medicinal claims made by the herbalists interviewed in this study.

\section{Limitations}

The dosage frequency, duration of treatment, and storage condition of the powdered plant material, decoctions, or concoctions were not captured during the interviews. Information on the duration of treatment was also not captured.

\section{Supplementary information}

Supplementary information accompanies this paper at https://doi. org/10.1186/s13020-020-00374-2. 
Additional file 1. Summary of the questionnaire used to interview herbalists in Kisumu East Sub County.

\section{Abbreviations}

LRTI: Lower respiratory tract infections; COPD: Chronic obstructive pulmonary disease; WHO: World Health Organization; BAUEC: Biosafety animal use and ethics committee; RFC: Relative frequency of citation.

\section{Acknowledgements}

The authors are grateful for the support of Mr. Peter Olewe and Mr. Kimeu Musembi for their assistance in data collection and identification of the medicinal plants collected from the study area.

\section{Authors' contributions}

JKM: Conceptualization, data curation, formal analysis, investigation, methodology, project administration, resources, visualization, writing original draft, and writing review and editing. JMN: Conceptualization, investigation, methodology, supervision, validation, writing review and editing. JMM: Conceptualization, investigation, methodology, supervision, validation, writing review and editing. MOO: Formal analysis, investigation, validation, visualization, writing original draft, writing review and editing. All authors read and approved the final manuscript.

\section{Funding}

This work did not receive any external funding.

\section{Availability of data and materials}

All data generated or analyzed during this study are included in the text.

\section{Ethics approval and consent to participate}

Ethical approval for the study was obtained from the Biosafety, Animal Use and Ethics committee of the University of Nairobi (Ref: FVM BAUEC/2019/210). Approval was additionally sought from regional administrators (the area chief and assistant chief) who were also duly made aware of the study's objectives. The scope, possible benefits and risks of the study were explained to all willing participants (practitioners of traditional medicine) and consent forms were made available to them for signing.

\section{Consent for publication}

Not applicable.

\section{Competing interests}

The authors declare no conflict of interest.

\section{Author details}

${ }^{1}$ Department of Public Health, Pharmacology, and Toxicology, Faculty of Veterinary Medicine, University of Nairobi, P.O Box 29053-00625, Nairobi, Kenya. 2 Department of Pharmacy, Kenya Medical Training College, Kisumu Campus Kenya, P.O Box 1594, Kisumu, Kenya. ${ }^{3}$ Department of Pharmacy, Jaramogi Oginga Odinga Teaching and Referral Hospital, P.O Box 849-40100, Kisumu, Kenya.

Received: 20 March 2020 Accepted: 19 August 2020

Published online: 03 September 2020

\section{References}

1. European Respiratory Society. The global impact of respiratory disease. 2nd ed. Sheffield: Forum of International Respiratory Societies; 2017.

2. Finney $\amalg$, Feary JR, Gordon SB, Mortimer K. Chronic obstructive pulmonary disease in sub-Saharan Africa : a systematic review. Int J Tuberc Lung Dis. 2013;17:583-9.

3. Murray CJL, Ezzati M, Flaxman AD, Lim S, Lozano R, Michaud C, et al. GBD 2010: a multi-investigator collaboration for global comparative descriptive epidemiology. The Lancet. 2012;380:2055-8. https://doi. org/10.1016/s0140-6736(12)62134-5.

4. Wang H, Naghavi M, Allen C, Barber RM, Bhutta ZA, Carter A, et al. Global, regional, and national life expectancy, all-cause mortality, and cause-specific mortality for 249 causes of death, 1980-2015: a systematic analysis for the Global Burden of Disease Study 2015. The Lancet. 2016:388:1459-544.

5. Home-Kenya National Bureau of Statistics, Nairobi, Kenya. https:// www.knbs.or.ke/. Accessed 13 Mar 2020

6. County K. Kisumu County Integrated Development Plan II, Vision: a peaceful and prosperous County where all citizens enjoy a high-quality life and a sense of belonging. Mission: To realize the full potential of devolution and meet the development aspirations of. 2018;2018:22.

7. Agyei-Baffour P, Kudolo A, Quansah DY, Boateng D. Integrating herbal medicine into mainstream healthcare in Ghana: clients' acceptability, perceptions and disclosure of use. BMC Complement Altern Med. 2017. https://doi.org/10.1186/s12906-017-2025-4.

8. Omoruyi BE. Ethnomedicinal survey of medicinal plants used for the management of HIV/AIDS infection among local communities of Nkonkobe Municipality, Eastern Cape, South Africa. J Med Plants Res. 2012. https://doi.org/10.5897/jmpr12.541.

9. Meragiaw M. Wild useful plants with emphasis on traditional use of medicinal and edible plants by the people of Aba'ala, North-eastern Ethiopia. J Med Plant Herb Ther Res. 2016;4:1-16.

10. Kisumu County-Kisumu. https://www.kisumu.go.ke/. Accessed 13 Mar 2020.

11. Tardio J, Pardo-de-Santayana M. Cultural importance indices: a comparative analysis based on the useful wild plants of Southern Cantabria (Northern Spain). Econ Bot. 2008;62:24-39. https://doi.org/10.1007/ s12231-007-9004-5.

12. Asnake S, Teklehaymanot T, Hymete A, Erko B, Giday M. Antimalarial medicinal plants used by Gumuz people of mandura woreda, Benishangul-Gumuz regional state, Ethiopia. India: NISCAIR-CSIR; 2016.

13. Demilew W, Adinew GM, Asrade S. Evaluation of the wound healing activity of the crude extract of leaves of Acanthus polystachyus Delile (Acanthaceae). Evid Based Complement Altern Med. 2018;2018:1-9. https://doi.org/10.1155/2018/2047896.

14. Derebe D, Wubetu M. Antimalarial activity of hydroalcoholic root extract of Acanthus polystachyus Delile (Acanthaceae) against Plasmodium berghei-infected mice. J Evid Based Integr Med. 2019;24:2515690X19885322.

15. Pascaline J, Charles M, George O, Lukhoba C. An inventory of medicinal plants that the people of Nandi use to treat malaria. J Anim Plant Sci. 2011;9:1192-200.

16. Kigondu EVM, Rukunga GM, Keriko JM, Tonui WK, Gathirwa JW, Kirira $P G$, et al. Anti-parasitic activity and cytotoxicity of selected medicinal plants from Kenya. J Ethnopharmacol. 2009;123:504-9. https://doi. org/10.1016/j.jep.2009.02.008

17. Kasali FM, Mahano AO, Kadima NJ, Mpiana PT, Ngbolua KN, Tshibangu TSD. Ethnopharmacological survey of medicinal plants used against malaria in Butembo City (DR Congo). J Adv Bot Zool. 2014;1:1-11.

18. Kankara SS, Ibrahim MH, Mustafa M, Go R. Ethnobotanical survey of medicinal plants used for traditional maternal healthcare in Katsina state, Nigeria. S Afr J Bot. 2015;97:165-75. https://doi.org/10.1016/j. sajb.2015.01.007.

19. Singh R, Singh S, Jeyabalan G, Ali A. An overview on traditional medicinal plants as aphrodisiac agent. J Pharmacogn Phytochem. 2012;1:43-56.

20. Sharma V, Sharma A, Kansal L. The effect of oral administration of Allium sativum extracts on lead nitrate induced toxicity in male mice. Food Chem Toxicol. 2010;48:928-36.

21. Al-Bekairi AM, Shah AH, Qureshi S. Effect of Allium sativum on epididymal spermatozoa, estradiol-treated mice and general toxicity. J Ethnopharmacol. 1990;29:117-25.

22. Benkeblia N. Antimicrobial activity of essential oil extracts of various onions (Allium cepa) and garlic (Allium sativum). LWT Food Sci Technol. 2004;37:263-8. https://doi.org/10.1016/j.lwt.2003.09.001.

23. Mikail HG. Phytochemical screening, elemental analysis and acute toxicity of aqueous extract of Allium sativum L. bulbs in experimental rabbits. J Med Plants Res. 2010;4:322-6.

24. Lawal B, Shittu OK, Oibiokpa FI, Mohammed H, Umar SI, Haruna GM Antimicrobial evaluation, acute and sub-acute toxicity studies of Allium sativum. J Acute Dis. 2016;5:296-301. 
25. Kareru PG, Gachanja AN, Keriko JMKGM. Antimicrobial activity of some medicinal plants used by herbalists. Afr J Tradit Complement Altern Med. 2008;5:51-5.

26. Kimondo J, Miaron J, Mutai P, Njogu P. Ethnobotanical survey of food and medicinal plants of the Ilkisonko Maasai community in Kenya. J Ethnopharmacol. 2015;175:463-9. https://doi.org/10.1016/j. jep.2015.10.013.

27. Kariuki HN, Kanui TI, Yenesew A, Mbugua PM, Patel NB. Antinociceptive activity of the root extracts of Rhus natalensis Kraus and Senna singueana. Phytopharmacology. 2012;2:312-7.

28. Matata DZ, Moshi MJ, Machumi F, Ngassapa OD, Swanepoel B, Oosthuizen $\mathrm{K}$, et al. Isolation of a new cytotoxic compound, 3-((Z)heptadec-14-enyl) benzene-1-ol from Rhus natalensis root extract. Phytochem Lett. 2020;36:120-6.

29. Taddese S, Asres K, Gebre-Mariam T. In vitro antimicrobial activities of some selected topically applied medicinal plants of Ethiopia. Ethiop Pharm J. 2003;21:39-46.

30. Bunalema L, Obakiro S, Tabuti JRS, Waako P. Knowledge on plants used traditionally in the treatment of tuberculosis in Uganda. J Ethnopharmacol. 2014;151:999-1004. https://doi.org/10.1016/j. jep.2013.12.020.

31. Lino A, Deogracious O. The in-vitro antibacterial activity of Annona senegalensis, Securidacca longipendiculata and Steganotaenia araliacea-Ugandan medicinal plants. Afr Health Sci. 2006;6:31-5.

32. Goma FM, Ezeala C, Nyirenda J, Chuba D, Prashar L, Simfukwe N, et al. Extraction and demonstration of uterotonic activity from the root of steganotaenia araliacea hochst. Med J Zambia. 2017;44:125-32.

33. Agunu A, Abdurahman EM, Andrew GO, Muhammed Z. Diuretic activity of the stem-bark extracts of Steganotaenia araliacea hochst [Apiaceae]. J Ethnopharmacol. 2005;96:471-5. https://doi. org/10.1016/j.jep.2004.09.045.

34. Capistrano IR, Wouters A, Foubert K, Balde AM, Apers S, Lardon F, et al. Phytochemical characterisation of a cytotoxic stem bark extract of Steganotaenia araliacea and identification of a protoflavanone by LC-SPE-NMR. Phytochem Lett. 2015:12:119-24.

35. Wickramaratne DBM, Pengsuparp T, Mar W, Chai H-B, Chagwedera TE, Beecher CWW, et al. Novel antimitotic dibenzocyclo-octadiene lignan constituents of the stem bark of Steganotaenia araliacea. J Nat Prod. 1993;56:2083-90.

36. Wang RW-J, Rebhun LI, Kupchan SM. Antimitotic and antitubulin activity of the tumor inhibitor steganacin. Cancer Res. 1977;37:3071-9.

37. Kariuki AC, Njoroge GN. Ethnobotanical and antimicrobial studies of some plants used in kibwezi (Kenya) for management of lower respiratory tract infections. Afr J Tradit Complement Altern Med. 2011;8:144-9.

38. Nedi T, Mekonnen N, Urga K. Diuretic effect of the crude extracts of Carissa edulis in rats. J Ethnopharmacol. 2004;95:57-61. https://doi. org/10.1016/j.jep.2004.06.017.

39. Kigen G, Kamuren Z, Njiru E, Wanjohi B, Kipkore W. Ethnomedical survey of the plants used by traditional healers in Narok County, Kenya. Evid Based Complement Altern Med. 2019;2019:1-8. https://doi. org/10.1155/2019/8976937.

40. Abdu KB, Khan ME, Rumah MM. Antimicrobial activity and phytochemical screening of extracts from the root bark of Carissa edulis, against human/animal pathogens. Cont J Trop Med. 2008;2:1.

41. Tolo FM, Rukunga GM, Muli FW, Njagi ENM, Njue W, Kumon K, et al. Antiviral activity of the extracts of a Kenyan medicinal plant Carissa edulis against herpes simplex virus. J Ethnopharmacol. 2006;104:92-9.

42. Leonard O, Robert S, Hoseah A, Charles M, Chepkorir R, Ngoci N. Phytochemical characterization and cytotoxicity of Carissa edulis, Azadirachta indica, Cassia siamea and Harrisonia abyssinica from Masumbi Village, Siaya County-Kenya. J Sci Res Rep. 2016;10:1-10.

43. Kirira PG, Rukunga GM, Wanyonyi AW, Muregi FM, Gathirwa JW, Muthaura CN, et al. Anti-plasmodial activity and toxicity of extracts of plants used in traditional malaria therapy in Meru and Kilifi Districts of Kenya. J Ethnopharmacol. 2006;106:403-7.

44. Tajehmiri A, Issapour F, Moslem MN, Lakeh MT, Kolavani MH. vitro antimicrobial activity of artemisia annua leaf extracts against pathogenic bacteria. Adv Stud Biol. 2014;6:93-7. https://doi.org/10.12988/ asb.2014.4525.
45. Iqbal S, Younas U, Chan KW, Zia-Ul-Haq M, Ismail M. Chemical composition of Artemisia annua L. leaves and antioxidant potential of extracts as a function of extraction solvents. Molecules. 2012;17:6020-32. https:// doi.org/10.3390/molecules17056020.

46. Nibret E, Wink M. Volatile components of four Ethiopian Artemisia species extracts and their in vitro antitrypanosomal and cytotoxic activities. Phytomedicine. 2010;17:369-74.

47. Zheng G-Q. Cytotoxic terpenoids and flavonoids from Artemisia annua. Planta Med. 1994;60:54-7.

48. Singh NP, Ferreira JFS, Park JS, Lai HC. Cytotoxicity of ethanolic extracts of Artemisia annua to Molt-4 human leukemia cells. Planta Med. 2011:77:1788-93.

49. Karaismailoglu MC. Investigation of the cytotoxic and genotoxic effects of Artemisia annua methanol extract with the Allium test. Ekoloji. 2014;23:64-74.

50. Efferth T, Herrmann F, Tahrani A, Wink M. Cytotoxic activity of secondary metabolites derived from Artemisia annua L. towards cancer cells in comparison to its designated active constituent artemisinin. Phytomedicine. 2011;18:959-69.

51. Guédé NZ, N'Guessan K, Dibié TE, Grellier P. Ethnopharmacological study of plants used to treat malaria, in traditional medicine, by Bete Populations of Issia (Côte d'ivoire). J Pharm Sci Res. 2010;2:216-27.

52. Akimanya A, Midiwo JO, Matasyoh J, Okanga F, Masila VM, Walker L, et al. Two polymethoxylated flavonoids with antioxidant activities and a rearranged clerodane diterpenoid from the leaf exudates of Microglossa pyrifolia. Phytochem Lett. 2015;11:183-7. https://doi.org/10.1016/j. phytol.2014.12.008.

53. Ochwang'i DO, Kimwele CN, Oduma JA, Gathumbi PK, Kiama SG, Efferth T. Cytotoxic activity of medicinal plants of the Kakamega County (Kenya) against drug-sensitive and multidrug-resistant cancer cells. J Ethnopharmacol. 2018:215:233-40.

54. Muganga R, Angenot L, Tits M, Frederich M. Antiplasmodial and cytotoxic activities of Rwandan medicinal plants used in the treatment of malaria. J Ethnopharmacol. 2010;128:52-7.

55. Mwanauta RW, Mtei KA, Ndakidemi PA. Prospective bioactive compounds from Vernonia amygdalina, Lippia javanica, Dysphania ambrosioides and Tithonia diversifolia in controlling legume insect pests. Agric Sci. 2014;05:1129-39.

56. Passoni FD, Oliveira RB, Chagas-Paula DA, Gobbo-Neto L, Da Costa FB. Repeated-dose toxicological studies of Tithonia diversifolia (Hemsl.) A. gray and identification of the toxic compounds. J Ethnopharmacol. 2013;147:389-94. https://doi.org/10.1016/j.jep.2013.03.024.

57. Elufioye TO, Agbedahunsi JM. Antimalarial activities of Tithonia diversifolia (Asteraceae) and Crossopteryx febrifuga (Rubiaceae) on mice in vivo. J Ethnopharmacol. 2004;93:167-71. https://doi.org/10.1016/j. jep.2004.01.009.

58. Liasu MO, Ayandele AA. Antimicrobial activity of aqueous and ethanolic extracts from Tithonia diversifolia and Bryum coronatum collected from Ogbomoso, Oyo State, Nigeria. Adv Nat Appl Sci. 2008;2:31-4.

59. Goffin E, Ziemons E, De Mol P, De Madureira MDC, Martins AP, Proença da Cunha A, et al. In vitro antiplasmodial activity of Tithonia diversifolia and identification of its main active constituent: Tagitinin C. Planta Med. 2002:68:543-5.

60. Kuroda M, Yokosuka A, Kobayashi R, Jitsuno M, Kando H, Nosaka K, et al. Sesquiterpenoids and flavonoids from the aerial parts of Tithonia diversifolia and their cytotoxic activity. Chem Pharm Bull. 2007;55:1240-4.

61. Wu TS, Shi LS, Kuo PC, Leu YL, Liou MJ, Wu PL, et al. Cytotoxic principles from the leaves of Tithonia diversifolia. Chin Pharm J. 2001:53:217-23.

62. Wahyuningsih MSH, Wijayanti MA, Budiyanto A, Hanafi M. Isolation and identification of potential cytotoxic compound from kembang bulan [Tithonia diversifolia (Hemsley) A. Gray] leaves. Int J Pharm Pharm Sci. 2015;7:298-301.

63. Liao M-H, Lin W-C, Wen H-C, Pu H-F. Tithonia diversifolia and its main active component tagitinin $C$ induce survivin inhibition and G2/M arrest in human malignant glioblastoma cells. Fitoterapia. 2011:82:331-41.

64. Chavez PI, Sánchez IA, Gonzalez FA, Rodríguez JL, Axelrod F. Cytotoxicity correlations of Puerto Rican plants using a simplified brine shrimp lethality screening procedure. Int J Pharmacogn. 1997;35:222-6. 
65. Chenia H. Anti-quorum sensing potential of crude Kigelia africana fruit extracts. Sensors. 2013;13:2802-17. https://doi.org/10.3390/s130302802

66. Grace OM, Light ME, Lindsey KL, Mulholland DA, van Staden J, Jager AK. Antibacterial activity and isolation of active compounds from fruit of the traditional African medicinal tree Kigelia africana. S Afr J Bot. 2002;68:220-2. https://doi.org/10.1016/s0254-6299(15)30424-5.

67. Owolabi OJ, Omogbai EKI, Obasuyi O. Antifungal and antibacterial activities of the ethanolic and aqueous extract of Kigelia africana (Bignoniaceae) stem bark. Afr J Biotechnol. 2007;6.

68. Arkhipov A, Sirdaarta J, Rayab P, McDonell PA, Cock IE. An examination of the antibacterial, antifungal, anti-Giardial and anticancer properties of Kigelia africana fruit extracts. Pharmacogn Commun. 2014;4:62-76. https://doi.org/10.5530/pc.2014.3.7.

69. Farah HM, El Hussein AM, Khalid HE, Osman HM. Toxicity of Kigelia africana fruit in rats. Adv Res. 2017. https://doi.org/10.9734/ AIR/2017/38539.

70. Moshi MJ, Van den Beukel CJ, Hamza OJM, Mbwambo ZH, Nondo ROS, Masimba PJ, et al. Brine shrimp toxicity evaluation of some Tanzanian plants used traditionally for the treatment of fungal infections. Afr J Tradit Complement Altern Med. 2007;4:219-25.

71. Onusiriuka BC, Ufodike EBC. Effects of sub-lethal concentrations of Akee Apple, Blighia sapida and Sausage Plant, Kigelia africana on Tissue Chemistry of African Catfish, Clarias gariepinus (L). J Aquat Sci. 2000;15:47-50.

72. Zofou D, Kengne ABO, Tene M, Ngemenya MN, Tane P, Titanji VPK. In vitro antiplasmodial activity and cytotoxicity of crude extracts and compounds from the stem bark of Kigelia africana (Lam) Benth (Bignoniaceae). Parasitol Res. 2011;108:1383-90.

73. Taura DW, Mukhtar MD, Adoum OA. Lethality of the aqeous extracts of Acacia nilotica, Guiera senegalensis, Kigelia africana and Securidaca longepedunculata on culex mosquito larva. Ife J Sci. 2004;6:115-8.

74. Mbunde MVN, Innocent E, Mabiki F, Andersson PG. Ethnobotanical survey and toxicity evaluation of medicinal plants used for fungal remedy in the Southern Highlands of Tanzania. J Intercult Ethnopharmacol. 2017;6:84.

75. Nadembega P, Boussim Jl, Nikiema JB, Poli F, Antognoni F. Medicinal plants in Baskoure, Kourittenga Province, Burkina Faso: an ethnobotanical study. J Ethnopharmacol. 2011;133:378-95. https://doi. org/10.1016/j.jep.2010.10.010

76. Akor JS, Anjorin TS. Phytochemical and antimicrobial studies of Commiphora africana root extracts. Int J Agric Biol. 2009;11:795-7.

77. Okwute SK, Ochi IO. Phytochemical analysis and cytotoxic activity of the root extract of Commiphora africana (Caesalpiniaceae). J Pharmacogn Phytochem. 2017;6:451-4.

78. Segun PA, Ogbole OO, Ismail FMD, Nahar L, Evans AR, Ajaiyeoba EO, et al. Resveratrol derivatives from Commiphora africana (A. Rich.) Endl. display cytotoxicity and selectivity against several human cancer cell lines. Phytother Res. 2019;33:159-66.

79. Maroyi A. Warburgia salutaris (Bertol. f.) Chiov.: a multi-use ethnomedicinal plant species. J Med Plants Res. 2013;7:53-60.

80. Kuglerova M, Tesarova H, Grade JT, Halamova K, Wanyana-Maganyi O, Van Damme P, et al. Antimicrobial and antioxidative effects of Ugandan medicinal barks. Afr J Biotechnol. 2011;10:3628-32.

81. Coopoosamy RM, Naidoo KK. An ethnobotanical study of medicinal plants used by traditional healers in Durban, South Africa. Afr J Pharm Pharmacol. 2012;6:818-23.

82. Otang WM, Grierson DS, Ndip N. Ethnobotanical survey of medicinal plants used in the management of opportunistic fungal infections in HIV/AIDS patients in the Amathole District of the Eastern Cape Province, South Africa. J Med Plants Res. 2012;6:2071-80.

83. Samie A, Mashau F. Antifungal activities of fifteen Southern African medicinal plants against five Fusarium species. J Med Plants Res. 2013:7:1839-48

84. Rabe T, van Staden J. Isolation of an antibacterial sesquiterpenoid from Warburgia salutaris. J Ethnopharmacol. 2000;73:171-4. https://doi. org/10.1016/s0378-8741(00)00293-2.

85. Soyingbe OS, Mongalo NI, Makhafola TJ. In vitro antibacterial and cytotoxic activity of leaf extracts of Centella asiatica (L.) Urb, Warburgia salutaris (Bertol. F.) Chiov and Curtisia dentata (Burm. F.) CA
Sm-medicinal plants used in South Africa. BMC Complement Altern Med. 2018;18:1-10.

86. Ngarivhume T, van't Klooster CIEA, de Jong JTVM, Van der Westhuizen $J$ H. Medicinal plants used by traditional healers for the treatment of malaria in the Chipinge district in Zimbabwe. J Ethnopharmacol. 2015;159:224-37. https://doi.org/10.1016/j.jep.2014.11.011.

87. Karou S, Agbodeka K, Gbekley H, Anani K, Agbonon A, Tchacondo T, et al. Ethnobotanical study of medicinal plants used for the treatment of malaria in the plateau region, Togo. Pharmacogn Res. 2016;8:12. https://doi.org/10.4103/0974-8490.178646.

88. Doughari JH, Elmahmood AM, Manzara S. Studies on the antibacterial activity of root extracts of Carica papaya L. Afr J Microbiol Res. 2007:1:37-41.

89. Otsuki N, Dang NH, Kumagai E, Kondo A, Iwata S, Morimoto C. Aqueous extract of Carica papaya leaves exhibits anti-tumor activity and immunomodulatory effects. J Ethnopharmacol. 2010;127:760-7.

90. Nguyen TT, Parat M-O, Hodson MP, Pan J, Shaw PN, Hewavitharana AK. Chemical characterization and in vitro cytotoxicity on squamous cell carcinoma cells of Carica papaya leaf extracts. Toxins. 2016;8:7.

91. Akinboro A, Bakare AA. Cytotoxic and genotoxic effects of aqueous extracts of five medicinal plants on Allium cepa Linn. J Ethnopharmacol. 2007;112:470-5.

92. Joseph B, Sankarganesh P, Ichiyama K, Yamamoto N. In vitro study on cytotoxic effect and anti-DENV2 activity of Carica papaya L. leaf. Front Life Sci. 2015:8:18-22.

93. Halim SZ, Abdullah NR, Afzan A, Rashid BAA, Jantan I, Ismail Z. Acute toxicity study of Carica papaya leaf extract in Sprague Dawley rats. J Med Plants Res. 2011;5:1867-72.

94. Afzan A, Abdullah NR, Halim SZ, Rashid BA, Semail RHR, Abdullah N, et al. Repeated dose 28-days oral toxicity study of Carica papaya L. leaf extract in Sprague Dawley rats. Molecules. 2012;17:4326-42.

95. Yamthe LR, David K, Ngadena YM. Acute and chronic toxicity studies of the aqueous and ethanol leaf extracts of Carica papaya Linn in Wistar rats. J Nat Prod Plant Resour. 2012;2:617-27.

96. Traore MS, Diane S, Diallo MST, Balde ES, Balde MA, Camara A, et al. In vitro antiprotozoal and cytotoxic activity of ethnopharmacologically selected guinean plants. Planta Med. 2014;80:1340-4.

97. Khalid H, Abdalla WE, Abdelgadir H, Opatz T, Efferth T. Gems from traditional north-African medicine: medicinal and aromatic plants from Sudan. Nat Prod Bioprospect. 2012;2:92-103. https://doi.org/10.1007/ s13659-012-0015-2.

98. Salih EYA, Kanninen M, Sipi M, Luukkanen O, Hiltunen R, Vuorela $\mathrm{H}$, et al. Tannins, flavonoids and stilbenes in extracts of African savanna woodland trees Terminalia brownii, Terminalia laxiflora and Anogeissus leiocarpus showing promising antibacterial potential. S Afr J Bot. 2017;108:370-86. https://doi.org/10.1016/j.sajb.2016.08.020.

99. Kaigongi MM, Musila FM. Ethnobotanical study of medicinal plants used by Tharaka people of Kenya. Int J Ethnobiol Ethnomed. 2015;1:1-8.

100. Kamita MK, Matu EN, Njenga EW, Wanga J, Amalemba G, Kigondu EVM. In vivo antifertility activity and phytochemical screening of selected Kenyan medicinal plants. Afr J Pharmacol Ther. 2014;3.

101. Thoria OO, Galal MA, Ashour NA, Hussain AM, Abdelrahman SH. Acute toxicity of the methanolic extracts of Terminalia brownii bark in rats. Res Opin Anim Vet Sci. 2012;2:122-6.

102. Onyango AO. An ethnobotanical, phytochemical, toxicity and efficacy study of selected antiblue-tick (boophilus decoloratus) herbal remedies for cattle of Suba sub-county. Kenya: University of Nairobi; 2016.

103. Kidane B, van Andel T, van der Maesen LJG, Asfaw Z. Use and management of traditional medicinal plants by Maale and Ari ethnic communities in southern Ethiopia. J Ethnobiol Ethnomed. 2014;10:46.

104. Cheikhyoussef A, Shapi M, Matengu K, Ashekele HM. Ethnobotanical study of indigenous knowledge on medicinal plant use by traditional healers in Oshikoto region, Namibia. J Ethnobiol Ethnomed. 2011;7:10. https://doi.org/10.1186/1746-4269-7-10.

105. Kamau LN, Mbaabu PM, Mbaria JM, Gathumbi PK, Kiama SG. Ethnobotanical survey and threats to medicinal plants traditionally used for the management of human diseases in Nyeri County, Kenya. Tang Humanit Med. 2016;6:21.1-21.15. https://doi.org/10.5667/tang.2016.0007.

106. Kaingu CK, Oduma JA, Kanui T. Preliminary investigation of contractile activity of Ricinus communis and Euclea divinorum extracts on isolated 
rabbit uterine strips. J Ethnopharmacol. 2012;142:496-502. https://doi. org/10.1016/j.jep.2012.05.026.

107. Ngari FW, Gikonyo NK, Wanjau RN, Njagi EM. Safety and antimicrobial properties of Euclea divinorum Hiern, chewing sticks used for management of oral health in Nairobi County, Kenya. J Pharm Biomed Sci. 2013;3:1-8.

108. Mothana RA, Al-Musayeib NM, Matheeussen A, Cos P, Maes L. Assessment of the in vitro antiprotozoal and cytotoxic potential of 20 selected medicinal plants from the island of Soqotra. Molecules. 2012;17:14349-60.

109. Kisangau DP, Hosea KM, Joseph CC, Lyaruu HVM. In vitro antimicrobial assay of plants used in traditional medicine in Bukoba Rural District, Tanzania. Afr J Tradit Complement Altern Med. 2008;4:510. https://doi. org/10.4314/ajtcam.v4i4.31245.

110. Kiswii TM, Monda EO, Okemo PO, Bii C, Alakonya AE. Efficacy of selected medicinal plants from Eastern Kenya against Aspergillus flavus. J Plant Sci. 2014;2:226-31.

111. Mwangi JW, Masengo W, Thoithi GN, Kibwage IO. Screening of some Kenyan medicinal plants using the brine shrimp lethality test. 1999.

112. Kipkore W, Wanjohi B, Rono H, Kigen G. A study of the medicinal plants used by the Marakwet Community in Kenya. J Ethnobiol Ethnomed. 2014;10:24.

113. Kaingu CK, Oduma JA, Mbaria JM, Kiama SG. Medicinal plants traditionally used for the management of female reproductive health dysfunction in Tana River County, Kenya. Tang Humanit Med. 2013;3(2):1-10

114. Muhi MQ, Mihale MJ, Mugoyela V, Henry L, Qwarse M, Mihale MJ, et al. Ethnobotanical survey of medicinal and pesticidal plants used by agropastoral communities in Mbulu District, Tanzania. Tanzan J Sci Technol. 2018; : $22-35$

115. Okoli AS, Okeke MI, Iroegbu CU, Ebo PU. Antibacterial activity of Harungana madagascariensis leaf extracts. Phytother Res. 2002;16:174-9.

116. Kengni F, Tala D, Djimeli M, Fodouop S, Kodjio N, Magnifouet H, et al. In vitro antimicrobial activity of Harungana madagascriensis and Euphorbia prostrata extracts against some pathogenic Salmonella sp. Int J Biol Chem Sci. 2013;7:1106.

117. Moulari B, Pellequer Y, Lboutounne H, Girard C, Chaumont J-P, Millet J, et al. Isolation and in vitro antibacterial activity of astilbin, the bioactive flavanone from the leaves of Harungana madagascariensis Lam. ex Poir. (Hypericaceae). J Ethnopharmacol. 2006;106:272-8. https://doi. org/10.1016/j.jep.2006.01.008.

118. Kengni F, Fodouop SPC, Tala DS, Djimeli MN, Fokunang C, Gatsing D. Antityphoid properties and toxicity evaluation of Harungana madagascariensis Lam (Hypericaceae) aqueous leaf extract. J Ethnopharmacol. 2016;179:137-45

119. Olagunju JA, Ogunfeibo AB, Ogunbosi AO, Taiwo OA. Biochemical changes elicited by isosaline leaf and stem-bark extracts of Harungana madagascariensis in the rat. Phytother Res. 2004;18:588-91.

120. Ngoupaye GT, Bum EN, Taiwe GS, Moto FCO, Talla E. Antidepressant properties of aqueous acerate from Gladiolus Dalenii corms. Afr J Tradit Complement Altern Med. 2014;11:53-61.

121. Gbadamosi IT. Evaluation of antibacterial activity of six ethnobotanicals used in the treatment of infectious diseases in Nigeria. Bot Res Int. 2012:5:83-9.

122. Odhiambo JA, Siboe GM, Lukhoba CW, Dossaji SF. Antifungal activity of crude extracts of gladiolus dalenii van geel (Iridaceae). Afr J Tradit Complement Altern Med. 2010;7:53-8.

123. Van Dyk S, Gerritsma-Van der Vijver LM, Van Der Nest DG. The toxicity of Gladiolus dalenii van Geel. Suid-Afrikaanse Tydskrif vir Natuurwetenskap en Tegnologie. 1994;13:125-8.

124. Fawole OA, Finnie JF, Van Staden J. Antimicrobial activity and mutagenic effects of twelve traditional medicinal plants used to treat ailments related to the gastro-intestinal tract in South Africa. S Afr J Bot. 2009;75:356-62.

125. Moshi MJ, Otieno DF, Mbabazi PK, Weisheit A. Ethnomedicine of the Kagera Region, north western Tanzania. Part 2: The medicinal plants used in Katoro Ward, Bukoba District. J Ethnobiol Ethnomed. 2010;6:19. https://doi.org/10.1186/1746-4269-6-19.

126. Moshi MJ, Otieno DF, Weisheit A. Ethnomedicine of the Kagera Region, north western Tanzania. Part 3: plants used in traditional medicine in Kikuku village, Muleba District. J Ethnobiol Ethnomed. 2012;8:14. https ://doi.org/10.1186/1746-4269-8-14.
127. Njeru S, Obonyo M, Nyambati S, Ngari S, Mwakubambanya R, Mavura $H$. Antimicrobial and cytotoxicity properties of the organic solvent fractions of Clerodendrum myricoides Kenyan traditional medicinal plant. J Intercult Ethnopharmacol. 2016;5:226. https://doi.org/10.5455/ jice.20160416122003.

128. Matu EN, van Staden J. Antibacterial and anti-inflammatory activities of some plants used for medicinal purposes in Kenya. J Ethnopharmacol. 2003;87:35-41. https://doi.org/10.1016/s0378-8741(03)00107-7.

129. Deressa T, Mekonnen $Y$, Animut A. In vivo anti-malarial activities of Clerodendrum myricoides, Dodonea angustifolia and Aloe debrana against Plasmodium berghei. Ethiop J Health Dev. 2010;24:25-9.

130. Irungu BN, Rukunga GM, Mungai GM, Muthaura CN. In vitro antiplasmodial and cytotoxicity activities of 14 medicinal plants from Kenya. S Afr J Bot. 2007;73:204-7.

131. Oryema C, Ziraba RB, Odyek O, Omagor N, Opio A. Phytochemical properties and toxicity to brine shrimp of medicinal plants in Erute county, Lira district, Uganda. J Med Plants Res. 2011;5:5450-7.

132. Kigen G, Maritim A, Some F, Kibosia J, Rono H, Chepkwony S, et al. Ethnopharmacological survey of the medicinal plants used in Tindiret, Nandi County, Kenya. Afr J Tradit Complement Altern Med. 2016;13:156. https://doi.org/10.4314/ajtcam.v13i3.19.

133. Nguta JM, Mbaria JM, Gakuya DW, Gathumbi PK, Kiama SG. Antimalarial herbal remedies of Msambweni, Kenya. J Ethnopharmacol. 2010;128:424-32. https://doi.org/10.1016/j.jep.2010.01.033.

134. Ngari EW. Ethnomedicne of Ogiek of River Njoro watershed, Nakuru, Kenya. Ethnobot Res Appl. 2010;8:135. https://doi.org/10.17348/ era.8.0.135-152.

135. Yashaswini S, Vasundhara M. Coleus (Plectranthus barbatus) - a multipurpose medicinal herb. Int Res J Pharm. 2011;2:47-58.

136. Govindarajan M, Rajeswary M, Hoti SL, Bhattacharyya A, Benelli G. Eugenol, a-pinene and $\beta$-caryophyllene from Plectranthus barbatus essential oil as eco-friendly larvicides against malaria, dengue and Japanese encephalitis mosquito vectors. Parasitol Res. 2016;115:807-15.

137. Borges Fernandes LC, Campos Câmara C, Soto-Blanco B. Anticonvulsant activity of extracts of Plectranthus barbatus leaves in mice. Evid Based Complement Altern Med. 2012. https://doi.org/10.1155/2012/860153.

138. Kapewangolo P, Hussein AA, Meyer D. Inhibition of HIV-1 enzymes, antioxidant and anti-inflammatory activities of Plectranthus barbatus. J Ethnopharmacol. 2013;149:184-90.

139. Lawi Y, Saria J, Kidukuli AW. Brine shrimp cytotoxicity, phytochemical screening and larvicidal activities of Plectranthus barbatus extracts. Res Rev Insights. 2018;2:1-4.

140. Amina M, Al-Musayeib NM, Alam P, Aleanizy FS, Alqahtni FY, Al-Said MS, et al. Cytotoxic evaluation and concurrent analysis of two diterpenes in the chloroform extract of Plectranthus barbatus using a validated HPTLC-UV method. Bull Chem Soc Ethiop. 2018;32:407-19.

141. Osuagwu GGE, Eme CF. The phytochemical composition and antimicrobial activity of Dialium guineense, Vitex doniana and Dennettia tripetala leaves. Asian J Nat Appl Sci. 2013;2:69-81.

142. Lagnika L, Amoussa M, Adjovi Y, Sanni A. Antifungal, antibacterial and antioxidant properties of Adansonia digitata and Vitex doniana from Bénin pharmacopeia. J Pharmacogn Phytother. 2012;4:44-52.

143. Fadeyi SA, Fadeyi OO, Adejumo AA, Okoro C, Myles EL. In vitro anticancer screening of 24 locally used Nigerian medicinal plants. BMC Complement Altern Med. 2013. https://doi.org/10.1186/1472-6882-13-79.

144. Muanda F, Koné D, Dicko A, Soulimani R, Younos C. Phytochemical composition and antioxidant capacity of three malian medicinal plant parts. Evid Based Complement Altern Med. 2011;2011:1-8. https://doi. org/10.1093/ecam/nep109.

145. Kilani AM. Antibacterial assessment of whole stem bark of Vitex doniana against some enterobactriaceae. Afr J Biotechnol. 2006;5.

146. Ali M, Aminu F, Ibrahim IS. In-vitro assessment of antibacterial activity and phytochemical screening of Vitex doniana on clinical isolate of Salmonella typhi. Int J Adv Acad Res. 2017;3:9-16.

147. Agbafor KN, Nwachukwu N. Phytochemical analysis and antioxidant property of leaf extracts of Vitex doniana and Mucuna pruriens. Biochem Res Int. 2011. https://doi.org/10.1155/2011/459839.

148. Amégbor K, Metowogo K, Eklu-Gadegbeku K, Agbonon A, Aklikokou KA, Napo-Koura G, et al. Preliminary evaluation of the wound healing effect of Vitex doniana sweet (Verbenaceae) in mice. Afr J Tradit Complement Altern Med. 2012;9:584-90. 
149. Abiodun O, Gbotosho G, Ajaiyeoba E, Happi T, Falade M, Wittlin S, et al. In vitro antiplasmodial activity and toxicity assessment of some plants from Nigerian ethnomedicine. Pharm Biol. 2011;49:9-14.

150. Belayneh A, Asfaw Z, Demissew S, Bussa NF. Medicinal plants potential and use by pastoral and agro-pastoral communities in Erer Valley of Babile Wereda, Eastern Ethiopia. J Ethnobiol Ethnomed. 2012;8:42. https :/doi.org/10.1186/1746-4269-8-42

151. Hamza OJM, van den Bout-van den Beukel CJP, Matee MIN, Moshi MJ, Mikx FHM, Selemani HO, et al. Antifungal activity of some Tanzanian plants used traditionally for the treatment of fungal infections. J Ethnopharmacol. 2006;108:124-32. https://doi.org/10.1016/j. jep.2006.04.026.

152. Kokila K, Priyadharshini SD, Sujatha V. Phytopharmacological properties of Albizia species: a review. Int J Pharm Pharm Sci. 2013;5:70-3.

153. Abdalla MA, Laatsch H. Flavonoids from Sudanese Albizia zygia (Leguminosae, subfamily Mimosoideae), a plant with antimalarial potency. Afr J Tradit Complement Altern Med. 2012;9:56-8.

154. Appiah-Opong R, Asante IK, Safo DO, Tuffour I, Ofori-Attah E, Uto T, et al. Cytotoxic effects of Albizia zygia (DC) J. F. Macbr, a Ghanaian medicinal plant, against human T-lymphoblast-like leukemia, prostate and breast cancer cell lines. Int J Pharm Pharm Sci. 2016:8:392-6.

155. Oloyede GK, Ogunlade AO. Phytochemical screening, antioxidant, antimicrobial and toxicity activities of polar and non-polar extracts of Albizia zygia (DC) stem-bark. Ann Res Rev Biol. 2013;3:1020-31.

156. Okpo SO, Igwealor CO, Eze Gl. Sub-acute toxicity study on the aqueous extract of Albizia zygia stem bark. J Pharm Bioresour. 2016;13:32.

157. Olarbi AA, Bekoe EO, Agyare C, Osafo N, Boamah VE. In vivo anti-inflammatory and antioxidant properties of Albizia zygia D. C. Macbr. Planta Med. 2016:81:S1-381. https://doi.org/10.1055/s-0036-1596353.

158. Pierre S, Alex NN, Jean M. Medicinal plants used in traditional treatment of malaria in Cameroon. J Ecol Nat Environ. 2011;3:104-17.

159. Ali A, Al-rahwi K, Lindequist U. Some medicinal plants used in Yemeni herbal medicine to treat malaria. Afr J Tradit Complement Altern Med. 2004; 1:72-6.

160. Doughari JH. Antimicrobial activity of Tamarindus indica Linn. Trop J Pharm Res. 2006;5:597-603.

161. Abukakar MG, Ukwuani AN, Shehu RA. Phytochemical screening and antibacterial activity of Tamarindus indica pulp extract. Asian J Biochem. 2008;3:134-8. https://doi.org/10.3923/ajb.2008.134.138.

162. Nwodo UU, Ngene AA, Anaga AO, Chigor VN, Henrietta II, Okoh AI. Acute toxicity and hepatotoxicokinetic studies of Tamarindus indica extract. Molecules. 2011;16:7415-27.

163. Abubakar MG, Yerima MB, Zahriya AG, Ukwuani AN. Acute toxicity and antifungal studies of ethanolic leaves, stem and pulp extract of Tamarindus indica. Res J Pharm Biol Chem Sci. 2010;1:104-11.

164. Adongo JO, Omolo JO, Njue AW, Matofari JW. Antimicrobial activity of the root extracts of Tylosema fassoglensis Schweinf. Torre \& Hillc (Caesalpiniaceae). Sci J Microbiol. 2012. https://doi.org/10.7237/sjmb/209.

165. Ochanga O, Chacha M. Antifungal and cytotoxicity activity of plants used as herbal teas in Tanzania. Eur J Med Plants. 2016;16:1-8. https:// doi.org/10.9734/ejmp/2016/29475.

166. Njoroge GN, Bussmann RW. Diversity and utilization of antimalarial ethnophytotherapeutic remedies among the Kikuyus (Central Kenya). J Ethnobiol Ethnomed. 2006;2:1-7.

167. Singh A, Kumar A, Tewari D. An ethnobotanical survey of medicinal plants used in Terai forest of western Nepal. J Ethnobiol Ethnomed. 2012;8:19. https://doi.org/10.1186/1746-4269-8-19.

168. Akpuaka A, Ekwenchi MM, Dashak DA, Dildar A. Biological activities of characterized isolates of $n$-hexane extract of Azadirachta indica A. Juss (Neem) leaves. NY Sci J. 2013;6:119-24.

169. Pandey G, Verma K, Singh M. Evaluation of phytochemical, antibacterial and free radical scavenging properties of Azadirachta indica (neem) leaves. Int J Pharm Pharm Sci. 2014;6:444-7.

170. Karou SD, Tchacondo T, Tchibozo MAD, Abdoul-Rahaman S, Anani K, Koudouvo K, et al. Ethnobotanical study of medicinal plants used in the management of diabetes mellitus and hypertension in the Central Region of Togo. Pharm Biol. 2011;49:1286-97. https://doi. org/10.3109/13880209.2011.621959.

171. Ugoh SC, Agarry OO, Garba SA. Studies on the antibacterial activity of Khaya senegalensis [(Desr.) A. Juss)] stem bark extract on Salmonella enterica subsp. enterica serovar Typhi [(ex Kauffmann and Edwards) Le
Minor and Popoff]. Asian Pac J Trop Biomed. 2014;4:S279-83. https:// doi.org/10.12980/apjtb.4.2014c636.

172. Muhammad I, Alhassan A, Sule M, Idi A, Mohammed A, Taalu AE, et al. Anti-hyperglycemic activity of solvents extract of Khaya senegalensis stem bark in alloxan induced diabetic rats. J Adv Biol Biotechnol. 2016;6:1-8. https://doi.org/10.9734/jabb/2016/25986.

173. Muhammad I, Alhassan A, Wudil A, Jarumi I. Toxicological and protective effect of aqueous stem bark extract of Khaya senegalensis (\{ASBEKS\}) on liver of experimental rat. Br J Appl Sci Technol. 2015;9:600-5. https://doi.org/10.9734/bjast/2015/16545.

174. Ibrahim MA, Koorbanally NA, Islam MS. Antioxidative activity and inhibition of key enzymes linked to type-2 diabetes (a-Glucosidase and a-Amylase) by Khaya senegalensis. Acta Pharm. 2014;64:311-24.

175. Yakubu MT, Adebayo OJ, Egwim EC, Owoyele VB. Increased liver alkaline phosphatase and aminotransferase activities following administration of ethanolic extract of Khaya senegalensis stem bark to rats. Nigerian Society for Experimental Biology; 2005.

176. Onu A, Saidu Y, Ladan MJ, Bilbis LS, Aliero AA, Sahabi SM. Effect of aqueous stem bark extract of Khaya senegalensis on some biochemical, haematological, and histopathological parameters of rats. J Toxicol. 2013. https://doi.org/10.1155/2013/803835.

177. Takin MC, Attindehou S, Sezan A, Attakpa SE, Lamine B-M. Bioactivity, therapeutic utility and toxicological risks of Khaya senegalensis. Indian J Pharm Biol Res. 2013;1:122-9.

178. Nagesh KS, Shanthamma C. Micropropagation and antioxidant activity of Mollugo nudicaulis Lam. J Med Plants Res. 2011;5:895-902.

179. Rameshkumar A, Sivasudha T. In vitro antioxidant and antibacterial activity of aqueous and methanolic extract of Mollugo nudicaulis Lam. leaves. Asian Pac J Trop Biomed. 2012;2:S895-900. https://doi. org/10.1016/s2221-1691(12)60332-3.

180. Sindhu T, Rajamanikandan S, Ragavendran P, Sophia D, Meenakshi P, Durgapriya D, et al. Antidiabetic activity of Mollugo nudicaulis against alloxan induced diabetic rats. Int J Appl Biol Pharm Technol. 2010;1:511-9.

181. Kasolo JN, Bimenya GS, Ojok L, Ochieng J, Ogwal-Okeng JW. Phytochemicals and uses of Moringa oleifera leaves in Ugandan rural communities. J Med Plants Res. 2010;4:753-7.

182. Caceres A, Cabrera O, Morales O, Mollinedo P, Mendia P. Pharmacological properties of Moringa oleifera. 1: Preliminary screening for antimicrobial activity. J Ethnopharmacol. 1991;33:213-6. https://doi. org/10.1016/0378-8741(91)90078-r.

183. Okumu MO, Ochola FO, Mbaria JM, Kanja LW, Gakuya DW, Kinyua AW et al. Mitigative effects of Moringa oleifera against liver injury induced by artesunate-amodiaquine antimalarial combination in wistar rats. Clin Phytosci. 2017;3:18. https://doi.org/10.1186/s40816-017-0052-9.

184. Berkovich L, Earon G, Ron I, Rimmon A, Vexler A, Lev-Ari S. Moringa oleifera aqueous leaf extract down-regulates nuclear factor-kappaB and increases cytotoxic effect of chemotherapy in pancreatic cancer cells. BMC Complement Altern Med. 2013;13:212.

185. Shahriar M, Hossain MI, Bahar ANM, Akhter S, Haque MA, Bhuiyan MA. Preliminary phytochemical screening, in-vitro antioxidant and cytotoxic activity of five different extracts of Moringa oleifera leaf. J Appl Pharm Sci. 2012;2:65

186. Nair S, Varalakshmi KN. Anticancer, cytotoxic potential of Moringa oleifera extracts on HeLa cell line. J Nat Pharm. 2011;2:138-42.

187. Basak SS, Candan F. Chemical composition and in vitro antioxidant and antidiabetic activities of Eucalyptus Camaldulensis Dehnh. essential oil. J Iran Chem Soc. 2010;7:216-26. https://doi.org/10.1007/bf03245882.

188. Ghalem BR, Mohamed B. Antibacterial activity of leaf essential oils of Eucalyptus globulus and Eucalyptus camaldulensis. Afr J Pharm Pharmacol. 2008;2:211-5

189. Adeniyi CBA, Lawal TO, Mahady GB. In vitro susceptibility of Helicobacter pylori to extracts of Eucalyptus camaldulensis and Eucalyptus torelliana. Pharm Biol. 2009;47:99-102.

190. Gemechu A, Giday M, Worku A, Ameni G. In vitro anti-mycobacterial activity of selected medicinal plants against Mycobacterium tuberculosis and Mycobacterium bovis strains. BMC Complement Altern Med. 2013 https://doi.org/10.1186/1472-6882-13-291.

191. Singab A-N, Ayoub N, Al-Sayed E, Martiskainen O, Sinkkonen J, Pihlaja K. Phenolic constituents of Eucalyptus camaldulensis Dehnh, with potential antioxidant and cytotoxic activities. Rec Nat Prod. 2011;5:271-80. 
192. El-Baha AM, El-Sherbiny AA, Salem MZM, Sharrawy NMM, Mohamed $\mathrm{NH}$. Toxicity of essential oils extracted from Corymbia citriodora and Eucalyptus camaldulensis leaves against Meloidogyne incognita under laboratory conditions. Pak J Nematol. 2017;35:93-104.

193. Hrubik JD, Kaišarević SN, Glišić $\mathrm{BD}$, Jovin $\mathrm{E}$, Mimica-Dukić NM, Kovačević RZ. Myrtus comunis and Eucalyptus camaldulensis cytotoxicity on breast cancer cells. Zbornik Matice srpske za prirodne nauke. 2012;123:65-73.

194. Soltanian S, Sheikhbahaei M, Mohamadi N. Cytotoxicity evaluation of methanol extracts of some medicinal plants on P19 embryonal carcinoma cells. J Appl Pharm Sci. 2017;7:142-9.

195. Ayyanar M, Subash-babu P. Syzygium cumini (L.) skeels: a review of its phytochemical constituents and traditional uses. Asian Pac JTrop Biomed. 2012;2:240-6.

196. Swami SB, Thakor NSJ, Patil MM, Haldankar PM. Jamun. Syzygium cumini: a review of its food and medicinal uses. Food Nutr Sci. 2012;03:1 100-17.

197. Muruganandan S, Srinivasan K, Chandra S, Tandan SK, Lal J, Raviprakash V. Anti-inflammatory activity of Syzygium cumini bark. Fitoterapia. 2001;72:369-75. https://doi.org/10.1016/s0367-326x(00)00325-7.

198. Saravanan G, Pari L. Hypoglycaemic and antihyperglycaemic effect of Syzygium cumini bark in streptozotocin-induced diabetic rats. J Pharmacol Toxicol. 2008;3:1-10. https://doi.org/10.3923/jpt.2008.1.10.

199. Ugbabe GE, Ezeunala MN, Edmond IN, Apev J, Salawu OA. Preliminary phytochemical, antimicrobial and acute toxicity studies of the stem, bark and the leaves of a cultivated Syzygium cumini Linn. (Family: Myrtaceae) in Nigeria. Afr J Biotechnol. 2010;9:6747-943.

200. Prasad M, Venugopal SP, Alagarsamy V, Sridevi C. The preliminary phytochemical analysis and oral acute toxicity study of stem bark of Syzygium cumini. Int J Pharm Pharm Sci. 2016:8:209-13.

201. Le NHT, Malterud KE, Diallo D, Paulsen BS, Nergård CS, Wangensteen $\mathrm{H}$. Bioactive polyphenols in Ximenia americana and the traditional use among Malian healers. J Ethnopharmacol. 2012;139:858-62. https://doi. org/10.1016/j.jep.2011.12.031.

202. Omer MEFA, Elnima El. Antimicrobial activity of Ximenia americana. Fitoterapia. 2003;74:122-6.

203. Maikai VA, Kobo PI, Maikai BVO. Antioxidant properties of Ximenia americana. Afr J Biotechnol. 2010;9:7744-6.

204. Cos P, Hermans N, De Bruyne T, Apers S, Sindambiwe JB, Vanden Berghe $D$, et al. Further evaluation of Rwandan medicinal plant extracts for their antimicrobial and antiviral activities. J Ethnopharmacol. 2002;79:155-63. https://doi.org/10.1016/s0378-8741(01)00362-2.

205. Habtamu A, Mekonnen Y. Antibacterial potential of the $80 \%$ methanol and chloroform extracts of Clematis hirsuta. Afr J Pharm Pharmacol. 2017;11:204-8.

206. Silva O, Duarte A, Cabrita J, Pimentel M, Diniz A, Gomes E. Antimicrobial activity of Guinea-Bissau traditional remedies. J Ethnopharmacol. 1996:50:55-9. https://doi.org/10.1016/0378-8741(95)01323-7.

207. Nureye D, Assefa S, Nedi T, Engidawork E. In vivo antimalarial activity of the $80 \%$ methanolic root bark extract and solvent fractions of Gardenia ternifolia Schumach. \&Thonn. (Rubiaceae) against Plasmodium berghei. Evid Based Complement Altern Med. 2018. https://doi. org/10.1155/2018/9217835.

208. Silva O, Barbosa S, Diniz A, Valdeira ML, Gomes E. Plant extracts antiviral activity against herpes simplex virus type 1 and African swine fever virus. Int J Pharmacogn. 1997;35:12-6. https://doi.org/10.1076/ phbi.35.1.12.13264.

209. Moshi MJ, Kamuhabwa A, Mbwambo Z, De Witte P. Cytotoxic screening of some Tanzania medicinal plants. East Cent Afr J Pharm Sci. 2003;6:52-6.

210. Aro AO, Dzoyem JP, Hlokwe TM, Madoroba E, Jacobus N, Mcgaw LJ. Some South African Rubiaceae Tree Leaf Extracts Have Antimycobacterial Activity Against Pathogenic and Non-pathogenic Mycobacterium species. Phytother Res. 2015;29:1004-1010. https://doi.org/10.1002/ ptr.5338

211. Fabry W, Okemo P, Ansorg R. Fungistatic and fungicidal activity of East African medicinal plants: Fungistatische und fungizide Wirksamkeit ostafrikanischer Heilpflanzen. Mycoses. 1996;39:67-70.

212. Balde AM, Pieters L, De Bruyne T, Geerts S, Berghe D, Vlietinck A. Biological investigations on Harrisonia abyssinica. Phytomedicine. 1995;1:299302. https://doi.org/10.1016/s0944-7113(11)80006-1.
213. Wabe N, Mohammed M, Raju N. An ethnobotanical survey of medicinal plants in the Southeast Ethiopia used in traditional medicine. Spatula. 2011;1:153. https://doi.org/10.5455/spatula.20110921101924.

214. Mascolo N, Pinto A, Capasso F, Yenesew A, Dagne E. Antipyretic and analgesic studies of the ethanalic extract of Teclea nobilis delile. Phytother Res. 1988;2:154-6.

215. Al Rehaily AJ, El Tahir KEH, Mossa JS, Rafatullah S. Pharmacological studies of various extracts and the major constituent, lupeol, obtained from hexane extract of Teclea nobilis in rodents. Nat Prod Sci. 2001;7:76-82.

216. Chayamiti T, Mwenje E, Mahamadi C. Spectrophotometric study of the anti-caseinolytic activity of root extracts of Teclea nobilis and Vepris zambesiaca on Bitis arietans venom. Afr J Pharm Pharmacol. 2013;7:1420-5.

217. Moshi MJ, Innocent E, Magadula JJ, Otieno DF, Weisheit A, Mbabazi PK, et al. Brine shrimp toxicity of some plants used as traditional medicines in Kagera region, north western Tanzania. Tanzan J Health Res. 2010;12:63-7.

218. Orwa JA, Jondiko IJO, Minja RJA, Bekunda M. The use of Toddalia asiatica (L) Lam. (Rutaceae) in traditional medicine practice in East Africa. J Ethnopharmacol. 2008;115:257-62.

219. Orwa JA, Ngeny L, Mwikwabe NM, Ondicho J, Jondiko IJO. Antimalarial and safety evaluation of extracts from Toddalia asiatica $(\mathrm{L})$ Lam. (Rutaceae). J Ethnopharmacol. 2013;145:587-90. https://doi.org/10.1016/j. jep.2012.11.034.

220. Borah R, Kalita MC, Kar A, Talukdar AK. Larvicidal efficacy of Toddalia asiatica (Linn.) Lam against two mosquito vectors Aedes aegypti and Culex quinquefasciatus. Afr J Biotechnol. 2010;9:2527-30.

221. Maobe MAG, Gitu L, Gatebe E, Rotich H, Karanja PN, Votha DM, et al. Antifungal activity of eight selected medicinal herbs used for the treatment of diabetes, malaria and pneumonia in Kisii Region, Southwest Kenya. World J Med Sci. 2013;8:74-8.

222. Kariuki H, Kanui T, Yenesew A, Patel N, Mbugua P. Antinocieptive and anti-inflammatory effects of Toddalia asiatica (L) Lam. (Rutaceae) root extract in Swiss albino mice. Pan Afr Med J. 2013. https://doi. org/10.11604/pamj.2013.14.133.2130.

223. Hirunwong C, Sukieum S, Phatchana R, Yenjai C. Cytotoxic and antimalarial constituents from the roots of Toddalia asiatica. Phytochem Lett. 2016;17:242-6.

224. Thirugnanasampandan R, Jayakumar R, Prabhakaran M. Analysis of chemical composition and evaluation of antigenotoxic, cytotoxic and antioxidant activities of essential oil of Toddalia asiatica (L.) Lam. Asian Pac JTrop Biomed. 2012;2:S1276-9.

225. Hu J, Shi X, Chen J, Mao X, Zhu L, Yu L, et al. Alkaloids from Toddalia asiatica and their cytotoxic, antimicrobial and antifungal activities. Food Chem. 2014;148:437-44.

226. Iwasaki H, Oku H, Takara R, Miyahira H, Hanashiro K, Yoshida Y, et al. The tumor specific cytotoxicity of dihydronitidine from Toddalia asiatica Lam. Cancer Chemother Pharmacol. 2006:58:451-9.

227. Tugume P, Kakudidi EK, Buyinza M, Namaalwa J, Kamatenesi M, Mucunguzi P, et al. Ethnobotanical survey of medicinal plant species used by communities around Mabira Central Forest Reserve, Uganda. J Ethnobiol Ethnomed. 2016. https://doi.org/10.1186/s13002-015-0077-4.

228. Kimani CN, Mbaria JM, Suleiman M, Gakuya D, Kiama SG. Antihyperglycemic activity of Zanthoxylum chalybeum stem bark extract in diabetic rats. J Phytopharmacol. 2015;4:183-9.

229. Nguta JM, Kiraithe MN. In vitro antimicrobial activity of aqueous extracts of Ocimum suave Willd., Plectranthus barbatus andrews and Zanthoxylum chalybeum Engl. against selected pathogenic bacteria. Biomed Biotechnol Res J. 2019;3:30.

230. Kiraithe MN, Nguta JM, Mbaria JM, Kiama SG. Evaluation of the use of Ocimum suave Willd. (Lamiaceae), Plectranthus barbatus Andrews (Lamiaceae) and Zanthoxylum chalybeum Engl. (Rutaceae) as antimalarial remedies in Kenyan folk medicine. J Ethnopharmacol. 2016;178:266-71. https://doi.org/10.1016/j.jep.2015.12.013.

231. Nguta JM, Mbaria JM, Gathumbi PK, Kabasa JD, Kiama SG. Biological screening of Kenya medicinal plants using artemia salina (ARTEMIIDAE). University of Nairobi Research Archive. 2011. http://erepository.uonbi .ac.ke/handle/11295/9787.

232. Omosa LK, Okemwa EK. Antiplasmodial activities of the stem bark extract and compounds of Zanthoxylum gilletii (De wild) P.G. Waterman. Pharmacogn Commun. 2017;7:41-6. https://doi.org/10.5530/ pc.2017.1.6. 
233. Nyaboke HO, Moraa M, Omosa LK, Mbaveng AT, Vaderament-Alexe N-N, Masila V, et al. Cytotoxicity of lupeol from the stem bark of Zanthoxylum gilletii against multi-factorial drug resistant cancer cell lines. Invest Med Chem Pharmacol. 2018;1:10

234. Omosa LK, Midiwo JO, Masila VM, Gisacho BM, Munayi R, Chemutai KP, et al. Cytotoxicity of 91 Kenyan indigenous medicinal plants towards human CCRF-CEM leukemia cells. J Ethnopharmacol. 2016;179:177-96.

235. Hussein S, Dhabe A. Ethnobotanical study of folk medicinal plants used by villagers in Hajjah district, Republic of Yemen. J Med Plants Stud. 2018;6:24-30

236. Alzoreky NS, Nakahara K. Antibacterial activity of extracts from some edible plants commonly consumed in Asia. Int J Food Microbiol. 2003:80:223-30. https://doi.org/10.1016/s0168-1605(02)00169-1.

237. Al-Mehdar AA, Al-Battah AM. Evaluation of hypoglycemic activity of boswellia carterii and cissus rotundifolia in streptozotocin/nicotinamide-induced diabetic rats. Yemeni J Med Sci. 2016;10:30-8.

238. Said A, Aboutabl EA, Melek FR, Abdel Jaleel Raheem Abdel Jaleel G, Raslan M. Phytoconstituents profiling of Cissus rotundifolia (Forssk.) Vahl. by HPLC-MS/MS, and evaluation of its free radical scavenging activity (DPPH) and cytotoxicity. Trends Phytochem Res. 2018;2:65-74.

239. Maima AO, Ndwigah SN, Thoithi GN, Kamau FN, Kibwage IO. Antimicrobial properties of some medicinal plants of the Luo Community of Kenya. Afr J Pharmacol Ther. 2014;3:112-5.

240. Lambert J, Omindi-ogaja E, Gatheru G, Mirangi T, Owara J, Herbst CH, et al. The contribution of traditional herbal medicine practitioners to Kenyan Health Care Delivery Results from Community Health-Seeking Behavior Vignettes and a Traditional Herbal Medicine Practitioner Survey. 2011.
241. Mukungu N, Abuga K, Okalebo F, Ingwela R, Mwangi J. Medicinal plants used for management of malaria among the Luhya community of Kakamega East sub-County, Kenya. J Ethnopharmacol. 2016;194:98107. https://doi.org/10.1016/j.jep.2016.08.050.

242. Christenhusz MJM, Byng JW. The number of known plants species in the world and its annual increase. Phytotaxa. Magnolia Press; 2016. pp. 201-17. http://biotaxa.org/Phytotaxa/article/download/phyto taxa.261.3.1/20598.

243. Alamgeer, Younis W, Asif H, Sharif A, Riaz H, Bukhari IA, et al. Traditional medicinal plants used for respiratory disorders in Pakistan: a review of the ethno-medicinal and pharmacological evidence Milen Georgiev, Ruibing Wang. Chin Med. 2018. https://doi.org/10.1186/s13020-018-0204-y.

244. Ahmed AA, Bassuony NI. Importance of medical herbs in animal feeding. World J Agric Sci. 2009;5:456-65.

245. Khan SM, Page S, Ahmad H, Harper D. Identifying plant species and communities across environmental gradients in the Western Himalayas: method development and conservation use. Ecol Inform. 2013;14:99-103.

246. Maroyi A. Traditional use of medicinal plants in South-Central Zimbabwe: review and perspectives. J Ethnobiol Ethnomed. 2013:9:1-18.

247. Dasaraju PV, Liu C. Infections of the respiratory system. In: Medical microbiology. 4th edition. Galveston: University of Texas Medical Branch; 1996.

\section{Publisher's Note}

Springer Nature remains neutral with regard to jurisdictional claims in published maps and institutional affiliations.
Ready to submit your research? Choose BMC and benefit from:

- fast, convenient online submission

- thorough peer review by experienced researchers in your field

- rapid publication on acceptance

- support for research data, including large and complex data types

- gold Open Access which fosters wider collaboration and increased citations

- maximum visibility for your research: over 100M website views per year

At BMC, research is always in progress.

Learn more biomedcentral.com/submissions 